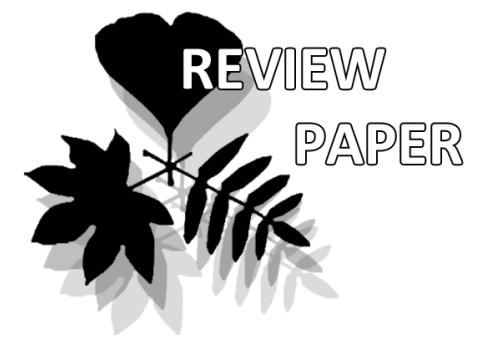

Gregory J. Retallack

e-mail: gregr@uoregon.edu

Department of Geological Sciences, University of Oregon, Eugene, Oregon 97403-1272, U.S.A.

Manuscript received: 16.07 .2015 Review completed: 14.08 .2015

Accepted for publication: 17.08 .2015

Published online: 20.08.2015

\section{Acritarch Evidence for an Ediacaran Adaptive Radiation of Fungi}

\author{
Gregory J. Retallack
}

\begin{abstract}
A B S T R A C T
Acritarchs are problematic organic-walled microfossils, traditionally regarded as phytoplankton, but also as cysts of metazoans or mesomycetozoans, and fungi. This review develops criteria for distinguishing these alternatives, and documents fungal features in several Precambrian acritarchs: (1) irregular shape, (2) hyphal attachment, (3) spherical wall protrusions, (4) septate and fused hyphae, (5) multilayered brittle walls that split and detach, (6) large size $(>100 \mu \mathrm{m})$, and (7) chitin and chitosan composition revealed by FTIR. Large acritarchs with fungal features are common and diverse during the Ediacaran, at the same time as extinct lichenlike Vendobionta. A different assemblage of small acritarchs diversified with the Cambrian evolutionary explosion of algae and metazoans. A fossil record of glomeromycotan fungi back to the Paleoproterozoic (2200 Ma) supports the idea of fungal life on land long before land plants, and an amended version of Pirozynski and Malloch's mycotrophic origin of early land plants.
\end{abstract}

K e y w o r d s : acritarch, Ediacaran, Glomeromycota, FTIR, wall ultrastructure

\section{P E 3 Ю M E}

Ретальак Г.Аж. Акритархи подтвержАают аАаптивную радиацию грибов. Акритархи - проб̆лемные микрофоссилии с органическими клеточными стенками, традиционно рассматриваются как фитопланктон, а также как цисты многоклеточных организмов, мезомицетов и грибов. Аанный обзор преАлагает критерии Аля разАичения этих групп организмов и анализ признаков нескольких групп Аокембрийских акритарх: (1) неправильная форма, (2) крепление гиф (3) сферические выступы клеточных стенок, (4) цельные гифы и гифы с перегородками (5) многослойные хрупкие и расслаивающиеся покровы (6) большой размер (> 100 мкм) и (7) соАержание хитина и хитозана, выявмяемое инфракрасной спектроксопией. Большие акритархи с признаками грибов обычны и разнообразны в эдиакарской биоте, в то время как михеноподобные организмы малочисленны. Сообщества небольших акритарх достигли наибольшего разнообразия во время кембрийского эвоцюционного взрыва водорослей и многоклеточных. Находки окаменелостей гломеромицетов вплоть до палеопротерозоя (2200 млн лет) подАерживают идею распространения жизни на суше в виле грибов заАолго Ао наземных растений и говорят в пользу версии происхожАения ранних наземных растений от микотрофных организмов, согласно Пирозинскому и Мальоку.

К $\mathbf{\Lambda}$ ю ч е в ы е с $\mathbf{\Lambda}$ в а : акритархи, эдиакарский периоА, гломеромицеты, инфракрасная спектроскопия, ультраструктура клеточных стенок

Переведено редкомлегией

\section{INTRODUCTION}

Molecular clocks now place the antiquity of fungi at about 2500-1000 Ma (Taylor \& Berbee 2006, Blair 2009, Berbee \& Taylor 2010). Other evidence for Proterozoic fungi have come from fossil compressions such as $2200 \mathrm{Ma}$ Diskagma (Retallack et al. 2013a), and 1480 Ma Horodyskia (Retallack et al. 2013b), permineralizations such as 2600575 Ma Eomycetopsis (Mendelson \& Schopf 1991, Altermann \& Schopf 1995), and Vendobionta such as $565 \mathrm{Ma}$ Fractifusus (Peterson et al. 2003, Gehling \& Narbonne 2007) and $550 \mathrm{Ma}$ Dickinsonia (Retallack 2007, 2013a). All these records are taxonomically unsatisfactory because they do not preserve microscopic reproductive structures of fungi, so a more promising source of biological information is the suggestion of Pirozynski (1976), Hermann (1979), Locquin (1983), Burzin (1993) and Butterfield (2005) that there is a Precambrian record of fungi among the enigmatic microfossil palynomorphs known as acritarchs (Grey 2005, Moczydłowska et al. 2011). This study follows the approach of Butterfield (2005) in reviewing benchmarks in the fossil record for particular fungal and animal-fungal characters, including hyphal attachment and fusion, bulbous wall protrusions, and brittle fracture. Also included is discovery of multilayered wall ultrastructure viewed by TEM and chitin composition revealed by FTIR (Table 1). This study also 
Table 1. Sources of FTIR spectra

\begin{tabular}{llll}
\hline Species & Higher taxon & Age & Reference \\
\hline Multifronsphaeridium pelorum & "acritarch" & Ediacaran & Arouri et al. 1999 \\
Leiosphaeridium jacutica & "acritarch" & Ediacaran & Marshall et al. 2005 \\
Satka squamulifera & "acritarch" & Ediacaran & Marshall et al. 2005 \\
Shuiyousphaeridium macroreticulatum & "acritarch" & Ediacaran & Marshall et al. 2005 \\
Botryococcus braunii & "acritarch" & Permian & Lin \& Ritz 1993 \\
Tasmanites punctatus & "acritarch" & Permian & Lin \& Ritz 1993 \\
Mucor rouxii & Mucorales, Zygomycota & modern & Wu et al. 2005 \\
Rhizopus stolonifer & Mucorales, Zygomycota & modern & Kaminskyj et al. 2008 \\
Fusarium avenaceum & Hypocreales, Ascomycota & modern & Calderón et al. 2009 \\
Metapenaeopsis dobsoni & Decapoda, Arthropoda & modern & Sini et al. 2007 \\
Bombus terrestris & Hymenoptera, Arthropoda & modern & Matján et al. 2007 \\
Protoceratium reticulatum & Gonyaulacales, Dinoflagellata & modern & Domenighini \& Giordano 2009 \\
Symbiodinium microadriaticum & Suessiales, Dinoflagellata & modern & Domenighini \& Giordano 2009 \\
Chlamydomonas reinhardtii & Volvocales, Chlorophyta & modern & Domenighini \& Giordano 2009 \\
Chlorella marina & Chlorellales, Chlorophyta & modern & Domenighini \& Giordano 2009 \\
\hline
\end{tabular}

tabulates the changing diversity of acritarchs and other plausible fungal megafossils as a proxy for evolutionary radiations in Precambrian fungi.

Acritarchs, like many palynomorphs, are an acknowledged taxonomic wastebasket for spheroidal organic-walled microfossils of unknown affinities (Grey 2005). Suggested affinities of acritarchs include Dinoflagellata, Prasinophyceae, Chlorophyceae, Fungi, Mesomycetozoa, and Metazoa. Dinoflagellates, prasinophytes and chlorophytes are aquatic eukaryotic phytoplankton (Moczydłowska et al. 2011). Fungi are marine and terrestrial, eukaroytic decomposers, and include acritarch-like structures in Glomeromycota, orders Glomales (mycorrhizae: Wu et al. 1995), and Archaeosporales (Geosiphon: Schüßler 2012), and Mucoromycotina (classification of Hibbett et al. 2007), Order Mucorales (molds: Pereyra et al. 2006). Mesomycetozoa are mostly fish parasites, but include spores with palintomic clusters of cells deceptively similar to animal embryos (Huldtgren et al. 2011). Choanoflagellates and arthropods, produce acritarch-like diapause cysts around embryos with cell differentiation (Cohen et al. 2009). This review suggests that some acritarchs were fungi, but other acritarchs were probably algae, mesomycetozoans and metazoans. As for palynological identifications, distinctive criteria are needed, and several are suggested here.

\section{DIAGNOSTIC FUNGAL FEATURES}

The following features are considered diagnostic of fungi, as opposed to algae, Mesomycetozoa or Metazoa, and may constrain their geological antiquity in the fossil record.

\section{Hyphal attachment}

A distinctive feature of fungal chlamydospores are attached tubular structures (hyphae) much longer than surficial spines or other ornament (Fig. 1: A-D). Tappania plana (Javaux et al. 2001) has the geologically oldest example of such features (at $1466 \pm 18 \mathrm{Ma}$ ). Such features are also characteristic of acritarch form-genera, such as Ceratosphaeridium (Fig. $1 \mathrm{E}$ ), whose name implies that this structure is a single oversize "horn" (Grey 2005), in other words, an unusual element of ornament. These elongate elements are hollow and open into the interior of the vesicle (Fig. 1 E,1: G H), so they are not surficial elaborations of the wall. Nor do they appear to be tubular structures spearing the vesicle, as suggested by Cavalier-Smith (2006), because they flare into the outer walls. The form-generic name Germinosphaera (Fig. $1 \mathrm{H}$ ) implies that the tubular feature was a germination tube, but that is an unlikely explanation given the comparable thickness and cutinization of walls of both the narrow tube and the large spherical body of the vesicle.

These long filaments of comparable materials to the spherical vesicle are similar to hyphae of Glomeromycotan spores, saccules and vesicles (Wu et al. 1995, Walker et al., 2004, Sieverding \& Oehl 2006, Pereyra et al. 2006, Schüßler 2012). Similar basal tubular strucutres and wall extensions are also found in the $2200 \mathrm{Ma}$ problematicum Diskagma (Retallack et al. 2013 a). Neither algae, mesomycetozoans, nor metazoans emerging from encystment construct single thick-walled tubes markedly narrower than the cyst (Cohen et al. 2009, Huldtgren et al. 2011).

\section{Hyphal fusion}

Sparsely septate hyphae which loop and fuse beyond the vesicle wall are best documented in palynomorphs of Tappania sp. (Butterfield 2005), which has the geologically oldest known examples of this feature (at $820 \pm 10 \mathrm{Ma}$ ). These hyphae form a three dimensional net around the vesicle from amalgamation of hyphae diverging at high angles to loop back toward the vesicle: open loops and unfused branches have been interpreted as an unfinished process of hyphal fusion and elaboration (Butterfield 2005).

Hyphal fusion of sparsely septate hyphae is not evidence of higher fungi (Dikarya = Ascomycota + Basidiomycota), as once thought by Butterfield (2005), because it has also been reported in Glomeromycota (Bever \& Wang 2005). Hyphal fusion is also found in Oomycota, which are no longer regarded as Fungi, but as Heterokonta (CavalierSmith 2006). Cell fusion is also known in vegetative cells of red and brown algae (Porter 2006) and pollen tubes of land plants (Berbee \& Taylor 2010). 

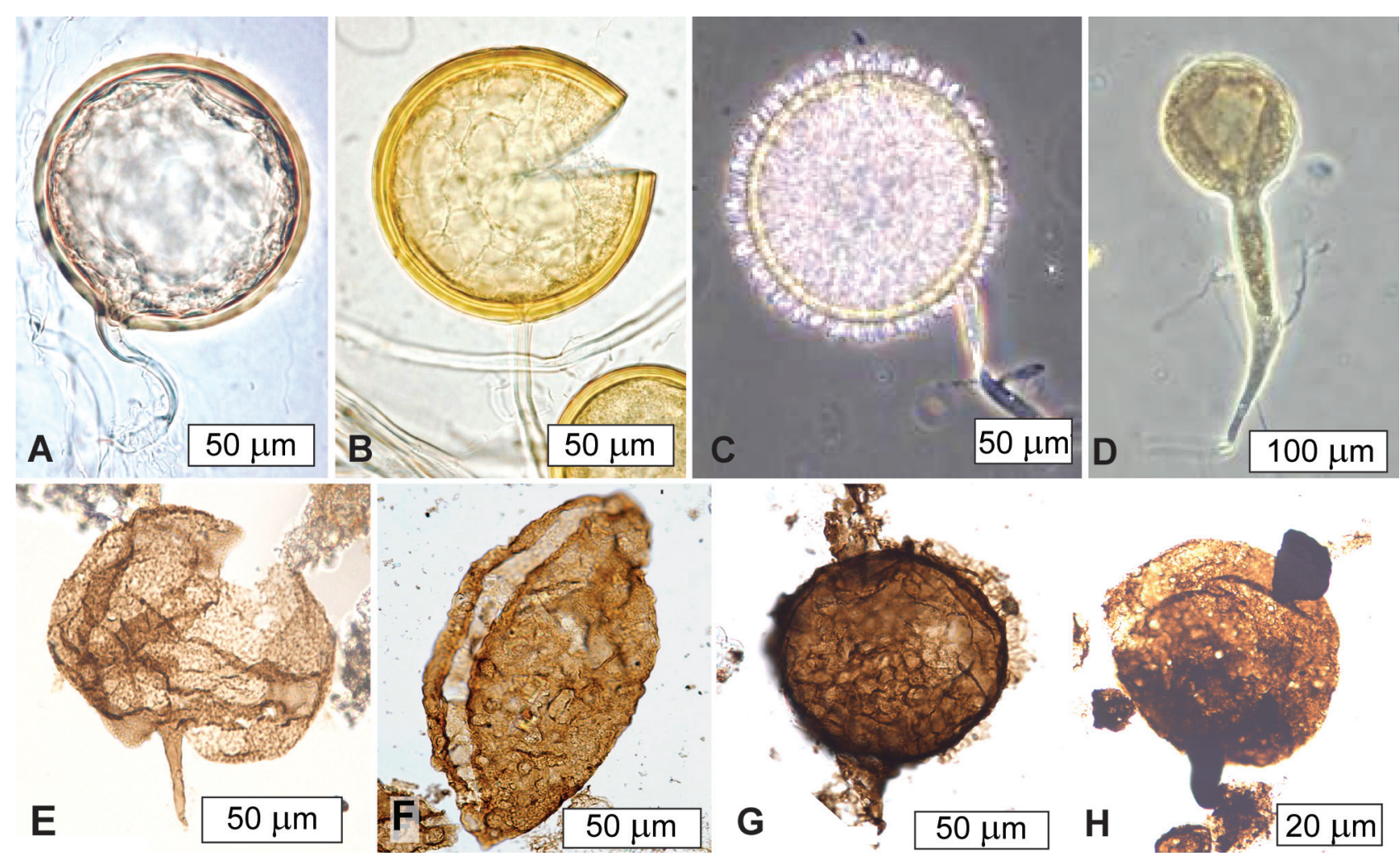

Figure 1 Modern fungal spores (A-C), and sporiferous saccule (D) and comparable Ediacaran acritarchs (E-H): (A) Glomus claroideum, Laukan, Finland: (B) Glomus intraradices, Îles de la Madeleine, Quebec, Canada: (C) Gerdemannia chimonobambusae, Nan-Tou, Taiwan (Wu et al. 1995; Walker et al. 2004); (D) Acaulospora kentinensis, Ping-tong, Taiwan (Wu et al. 2005; Sieverding \& Oehl 2006; Kaonongbua et al. 2010); (E) Ceratosphaeridium mirabile, Wilari Dolomite Member, Tanana Formation, Observatory Hill no., 1 well, northern South Australia (Grey 2005); (F) Schizofusa zangwenlongii, Dey Dey Mudstone, Observatory Hill bore, northern South Australia (Grey 2005); (G) Appendisphaera centroreticulata, Tanana Formation, Munta 1 bore, northern South Australia (Grey 2005); (H) Germinosphaera sp. indet. ABC Range Quartzite, SCYW1a bore, South Australia (Grey 2005): (A-B) by Yolande Dalpé, (C-D) by Chiguang Wu, and (E-H) by K. Grey, with permission

\section{Bulbous wall protrusions}

Bulbous wall protrusions are common on vesicles of Tappania (Javaux et al. 2001, Butterfield 2005). They are not walls of foreign invading cells such as mycoparasites (Taylor \& Osborn 1996), because TEM imaging of protrusions in Tappania (Javaux et al. 2004), Leiospheridia and Gyalosphaeridium (Willman 2009), shows that they balloon out of the internal cavity, and share walls with the same ultrastructural layers, rather than forming callus or reaction tissue.
Javaux et al. (2001) suggested that these wall protrusions were a form of vegetative propagation by budding, implying a protistan affinity. But both walls and spherical protrusions are invested in an acid-resistant biopolymer wall similar to that of the larger structure from which they emerge (Javaux et al. 2004). This kind of wall and arrangement is comparable with vesicles and saccules in Glomeromycotan fungi (Stürmer \& Morton 1999).
Figure 2 Murographs (A-C) and TEM sections (D-F) of Ediacaran acritarchs (D-E) and a modern fungal spore (F): (A, D) Leiosphaeridia sp indet., from Dey Dey Mudstone (Ediacaran), Murnarnoo borehole, northern South Australia (Willman 2009); (B, E) Gyalosphaeridium pulchrum, same locality as (A, D) (Willman 2009): (C, F, Mucor rouxii sporangiophore (Pereyra et al. 2006). Images courtesy of S. Willman (D-E) and E. Pereyra (F), with permission. Murographs follow conventions of Walker (1983)

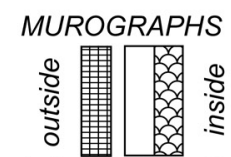

A. Leiosphaeridia

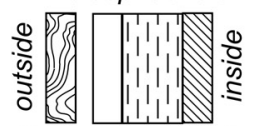

B. Gyalosphaeridium

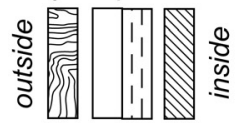

C. Mucor rouxi

ए्या) perine $\square$ unit

L. Th laminated

membranous

notching

amorphous
D.
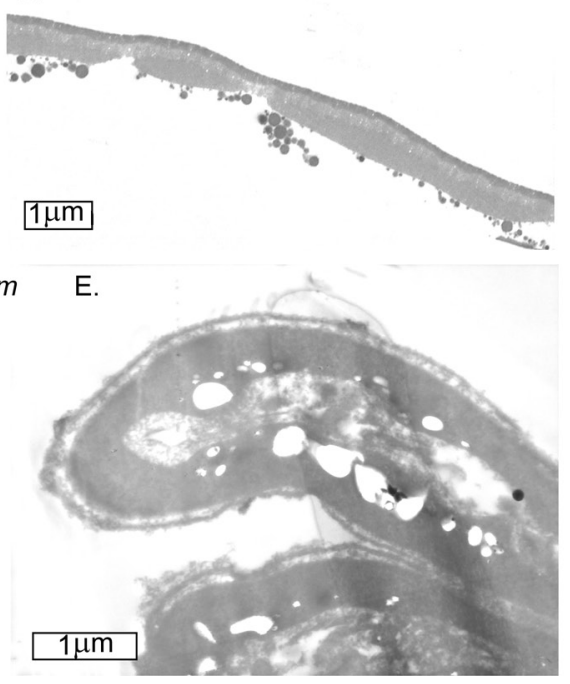

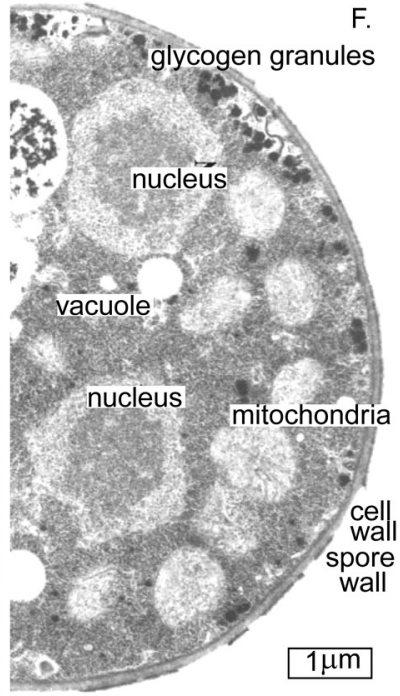




\section{Brittle fracture}

Elongate sharp slits are characteristic of large smooth acritarchs such as Leiosphaeridia and Schizofusa (Fig. 1 F), and the oldest known example at $820 \pm 10 \mathrm{Ma}$ is Tappania sp. (Butterfield 2005, Fig. 1 A). These were not broken during laboratory maceration and mounting of the specimens, because the edges of the splits in the fossils had their outlines thinned and pitted by bacterial decay and framboid growth, which predated burial carbonization (Fig. 1 F). These features are at one end of a spectrum of decay, or taphonomic series, documented for Ediacaran acritarchs by Grey \& Willman (2009).

These observations and the elongate sharp slits are evidence of walls that were brittle and tough like chitin, rather than pliable and crushable like cell walls of algal cellulose and algenan. Modern spores of Glomus show comparable breakage with pressure on the cover slip, often deliberately applied to reveal this diagnostic frangibility of wall layers (Fig. 1 B).

\section{Multilayered walls}

Some acritarchs examined by TEM (Fig. 2: D-E) and as old as $580 \pm 4 \mathrm{Ma}$ have a three-layer wall: (1) outermost thin and very electron-dense layer, (2) central electrontenuous layer, and (3) inner thick moderately electrondense layer (Willman 2009, Moczydłowska et al. 2010). Wall differentiation is also demonstrated by wrinkling and pulling away of the innermost from the outer walls of some acritarchs (Grey \& Willman 2009). Geologically older vesicles examined by TEM do not show differentiated layers (Javaux et al. 2010).

Multilayered vesicle walls are comparable with spore walls of Glomeromycota (Koske \& Walker 1986, Koske \& Gemma 1995), and cyst walls of Mesomycetozoa (Pekkarinen et al. 2003) and Metazoa (Cohen et al. 2009). Separation and folding of an inner membranous wall in Ediacaran acritarchs (Grey \& Willman 2009) is also characteristic of Glomalean fungal spores (Fig. $1 \mathrm{~A}$ ). Multiple layers of mesomycetozoan and metazoan cyst walls are not separable (Cohen et al. 2009). Algal and Paleozoic acritarchs are quite different under TEM (Talyzina \& Moczydłowska 2000), showing radial pores within a thick wall (Tasmanites), or homogeneous cell walls (Comasphaeridium, Globosphaeridium, Skiagia).

Walker (1983) proposed a system of murographs for description of glomalean fungal walls, and this system has been applied to two fossil acritarchs and one modern spore in Fig. 2. The murograph of the Ediacaran acritarch Leiosphaeridia sp. (Fig. $2 \mathrm{~A}$ ) is similar to that the living glomalean fungus Scutellospora hawaiiensis (Koske \& Gemma 1995), although the fossil inner wall has been effaced in patches. The murograph of Gyalosphaeridium pulchrum (Fig. 2 B) is more typical of glomalean fungi, such as Glomus globiferum (Koske \& Walker 1986) and G. macrocarpum (BonfanteFasolo \& Schubert 1987) and archaeosporalean fungi, such as Geosiphon pyriformis (Schüßler et al. 1994).

\section{DIAGNOSTIC FUNGAL-ANIMAL FEATURES}

The following features distinguish microfossils from algae, but not Mesomycetozoa and Metazoa. A simplified phyletic distribution of these characters is shown in Fig. 3.

\section{Chitin composition}

Ediacaran acritarchs as ancient as $580 \pm 4$ Ma show FTIR spectra (Figs 4: A-D) that closely match chitin and chitosan (Figs. 4: G-M), with 5 characteristic absorption bands (Wu et al. 2005): at wave numbers 3400-3480, 2900, 1650, 1557, $1370 \mathrm{~cm}^{-1}$. Chitosan is deacetylated chitin, produced industrially by leaching with $\mathrm{NaOH}$, but also produced by fermentation with bacteria (Rao \& Stevens 2005). This is an appealing explanation for the chitosan composition of some Ediacaran acritarchs, because they also show local dissolution, framboids and shredding comparable with bacterial degradation (Grey \& Willman 2009).

Only one of the five FTIR absorption bands for chitin and chitosan is found in fossil algae (Botryococcus and Tasmanites, Fig. 4: E-F) and only two of these bands are found in modern Oomycota (Helbert et al. 1997), and algae (Fig. 4: $\mathrm{N}-\mathrm{Q})$. Chitin has been reported from chlorophyte algae such as Chlorella (Němcová 2003), bacillariophytes such as Thalassiosira (McLachlan et al. 1965) and chrysophytes such as Poteriochromas (Herth et al. 1977), but it is a minor component of the wall in microfibrils within a matrix of cellulose, which would add noise to FTIR spectra. There is genomic evidence that chitin microfibrils in algae are produced by phycoadnaviral infection (van Etten \& Meints 1999, Kawasaki et al. 2002, Ali et al. 2007). Chitin and chitosan are widespread and dominate cell walls of fungi, including Chytridiomycota, Glomeromycota, Basidiomycota and Ascomycota (Bartnicki-Garcia 1968, Wu et al. 2005, Kaminskyj et al. 2008, Calderón et al. 2009), as well as exoskeletons of arthropods (Sini et al. 2007, Matján et al. 2007).

\section{NON-DIAGNOSTIC FEATURES}

The following features have been regarded as benchmarks in acritarch evolution, but are too widespread or uncertain to be distinctive of particular clades.

\section{Large size}

Unusually large size is a feature of Ediacaran acritarchs permissive of fungal affinities, but shared by mesomycetozoan and metazoan cysts (Cohen et al. 2009, Huldtgren et al. 2011), algal phycomata (Colbath 1983), giant sulphur bacteria such as Thiomargarita namibiense (Bailey et al. 2007), and actinobacteria such as Amycolatopsis decaplanina (Cavalier-Smith 2006). Most Phanerozoic acritarchs and modern unicellular algae are $20-50 \mu \mathrm{m}$ in diameter, whereas Precambrian smooth and spiny acritarchs range in size from 20-500 $\mu \mathrm{m}$ in diameter, with a modal diameter of $220 \mu \mathrm{m}$ (Cohen et al. 2009).

\section{Cell inclusions}

Also permissive of fungal-holozoan-metazoan affinities are inclusions within Ediacaran acritarchs. Electrondense granules seen inside some Ediacaran acritarch walls (Fig. 2 E) are comparable with glycogen granules, and other inclusions (Fig. $2 \mathrm{E}$ ) are similar to nuclei and mitochondria of Glomeromycota (Fig. 2F). Large internal bodies with accommodating sides in Mesomycetozoa (Pekkarinen et al. 2003, Huldtgren et al. 2011) are morphologically similar to an early (morula) stage of metazoan embryonic de- 
velopment. Comparable internal contents within the Ediacaran acritarch Tianzhushania, have never been found beyond what would be a morula stage of a metazoan (Xiao et al. 2012, Schiffbauer et al. 2012, Yin et al. 2013).

\section{Surface ornament}

Spiny outer surfaces do not exclude fungal affinities, and are common in all the organisms under consideration (Arouri et al. 1999, 2000, Cohen et al. 2009, Moczydłowska et al. 2011, Yin et al. 2013). Many spores of Glomeromycota are smooth, but not all: spiny acritarchs such as Appendisphaera (Fig. $1 \mathrm{G}$ ) are comparable with spores of Glomalean fungi such as Gerdemannia (Fig. $1 \mathrm{C}$ ).

\section{PRECAMBRIAN FUNGAL BENCHMARKS}

The various fungal features discussed can be used to reassess specific occurrences as potential benchmarks in the palynological record of fungi: specifically $1466 \pm$ $18 \mathrm{Ma}$ minimum age of Glomeromycota, and $599 \pm 4 \mathrm{Ma}$ appearance of lichenized Mucoromycotina. Despite claims of Butterfield (2005) and Schopf \& Barghoon (1969) for evidence of Precambrian higher fungi (Ascomycota and Basidiomycota), these clades are not convincingly represented by Precambrian palynomorphs (Strother et al. 2011), and remain unknown older than Silurian (Sherwood-Pike \& Gray 1985, Taylor \& Osborn 1986, Burgess \& Edwards 1991, Taylor \& Taylor 2000, Taylor et al. 1997, 2005, 2014, Honegger et al. 2013, Matsunaga et al. 2013).

\section{$1466 \pm 18 \mathrm{Ma}$ and $820 \pm 10 \mathrm{Ma}$ Glomeromycota}

Tappania plana from the $1466 \mathrm{Ma}$ Roper River Group of Northern Territory has the following fungal features: irregular polyhedral-spherical shape, large size (up to $160 \mu \mathrm{m}$ ), spherical cell wall protrusions, and hyphal attachment (Javaux et al. 2001). The palynomorphs show what appears to be several wall layers, but TEM examination of a very deformed specimen showed little detail and was interpreted as massive (Javaux et al. 2004). Tappania sp. indet. from the $820 \mathrm{Ma}$ Wyniatt Formation of Nunavut has in addition elongate and lobate shapes, rhizine-like attachments, fused hyphae, and sizes up to $300 \mu \mathrm{m}$ long (Butterfield 2005).

Tappania from the shallow marine facies of the lower Corcoran Formation and shoreface facies of the upper Jalboi Formation of the Roper River Group in the McArthur Basin, Northern Territory (Javaux et al. 2010) is bracketed by a U-Pb SHRIMP zircon age of $1492 \pm 4 \mathrm{Ma}$ from an ash bed below, and an Rb-Sr isochron age of for $1429 \pm$ $31 \mathrm{Ma}$ on illite in dolomitic siltstones near the top of the succession (Kralik 1982, Page et al. 2000). Interpolating between these ages and errors gives $1466 \pm 18 \mathrm{Ma}$ for the fossiliferous levels.

A more varied suite of Tappania and similar Germinosphaera fossils from shallow marine shales of the lower Wynniatt Formation, on Victoria Island, Nunavut (Butterfield 2005), is associated with cyanobacterial microfossils as evidence of deposition within the photic zone (Butterfield \& Rainbird 1998). The lower Wynniatt Formation is older than Franklin diabase intrusions dated by $\mathrm{U} / \mathrm{Pb}$ on baddeleyite at $716.33 \pm 0.54 \mathrm{Ma}$ (MacDonald et al. 2010), and younger than detrital zircons from sandstone dated by U-Pb at $1077 \pm 4 \mathrm{Ma}$ (Rainbird et al. 1996). Wynniatt Formation carbon isotopic data is evidence of an age immediately before (only $20 \mathrm{~m}$ below) the onset of the Bitter Springs anomaly, which in turn is dated by $\mathrm{U} / \mathrm{Pb}$ on zircons in a tuff at $811.5 \pm 0.25 \mathrm{Ma}$ in the Ogilvie Mountains of northwest Canada (MacDonald et al. 2010). Chemostratigraphic correlation gives an age of $820 \pm 10 \mathrm{Ma}$ for the lower Wynniatt Formation (Jones et al. 2010).

In retrospect it is surprising that Tappania was included within acritarchs, which are more regularly spherical and have sharply ending, and radially arranged processes (Moczydłowska et al. 2011). Fusion of sparsely septate hyphae is not evidence of higher fungi (Ascomycota + Basidiomycota), as once thought (Butterfield 2005), because hyphal fusion and septae are now known in Glomeromycota (Bever \& Wang 2005), as well as Oomycota, algae and Plantae (Porter 2006, Berbee \& Taylor 2010). Considered in this new light, Tappania may be compared with saccules of extant Acaulospora kentinensis (Fig. 1 D), spores of extant Gerdemannia chimonobambusae (Fig. $1 \mathrm{C}$ ), and fungal sclerotia (Moore 2013). Unlike these living taxa, it was not mycorrhizal with land plants, and did not show germination shields. Tappania is covered in hyphae unlike glomalean spores (Pirozynski \& Dalpé 1989) and the endosymbiotic bladders of the glomeromycotan Geosiphon (Schüßler 2012). Tappania also appears hollow, unlike sclerotia (Moore 2013). It is here regarded as a glomeromycotan saccule.

Fungal affinities of Tappania have been disputed. Cavalier-Smith (2006) compared Tappania with actinobacterial pseudosporangia like those of living Amycolatopsis decaplanina, while admitting that actinobacteria are smaller and less complex. Porter (2006) and Berbee \& Taylor (2010) noted that cell fusion is also found in vegetative cells of red and brown algae, between antheridia and oogonia of Oomycota, and pollen tube and embryo sac in plants, but these are not fused septate hyphae. Porter (2006) and Javaux (2007) also questioned whether the Wynniatt Formation material could be referred to Tappania, because hyphal fusion was not illustrated in holotypes of Tappania from the Beidajian Formation by Yin (1997). The holotypes had short broken hyphae, known to be a consequence of rough treatment during preparation, but even if the name is incorrect, that does not falsify the observed features (Butterfield 2005). Berbee \& Taylor (2010) found similarities between the hyphal mesh of Tappania and fungal adaptations for animal dispersal, but the neatness of the mesh in some specimens is also a taphonomic-preparation artefact, as shown by more ragged examples (Butterfield 2005), including rhizine-like extensions (Butterfield 2005: grading into "Germinosphaera"). Rhizine-like structures are significant because Berbee \& Taylor (2010) mistakenly assumed they were lacking. The statement of Moczydłowska et al. (2011) that "Fungal spores have no morphologically complex processes like .... acritarch genera", is also untrue (Fig. 1: C-D). Moczydłowska et al. (2011) also consider collar-like extensions of the wall of Tappania to be algal excystment structures, rather than fungal hyphae or rhizines, but excystment structures are not collars, but slits, often defining an operculum, as demonstrated by fossil (Yuan et al. 2001) and living microbes (Bowers \& Korn 1969). 


\section{$599 \pm 4$ Ma cyanolichen}

An un-named permineralized cyanolichen from the Doushantuo Formation near Weng'an, China, has been reported from bituminous phosporites (Yuan et al. 2005). The phosphorite has been dated by several methods, the most precise based on $\mathrm{U}-\mathrm{Pb}$ on apatite from the fossil bed yielded an age of $599.2 \pm 4.3 \mathrm{Ma}$ (Barfod et al. 2002). This date is supported by additional bracketing dates of Condon et al. (2005).

This fossil is a lichenlike association of phosphate-permineralized branching hyphae with terminal saccules or spores intimately associated with coccoid cells, and has been interpreted as a mucoromycotan host to cyanobacterial photobiont by Yuan et al. (2005). Such close association of mycobiont and phycobiont is typical of ascolichens and basidiolichens (Honegger et al. 2013, Matsunaga et al. 2013), but unknown in any living Glomeromycota or Mucromycotina, and so represents an extinct clade of ectolichens. The only extant symbiotic glomeromycotans are endocyanotic Geosiphon (Schüßler 2012), and such endosymbiosis is not accepted as a true "lichen" in some quarters (Hawksworth \& Honegger 1994).

The Weng'an lichen fossil has been assumed to have been marine like associated fossil algae (Xiao et al. 2004) and mesomycetozoans (Huldtgren et al. 2011), but recent mineralogical study suggests that the Doushantuo Formation was deposited in a lake (Bristow et al. 2009). Furthermore the fossil is a rare small fragment only $0.5-5 \mathrm{~m}$ stratigraphically above a paleokarst (Yuan et al. 2005). More complete remains are needed, and presumably available from this well sampled locality (Bengtson et al. 2012), to determine whether this fossil was aquatic or terrestrial.

\section{$583 \pm 2.3$ Ma brittle multilayered chitin walls}

Leiosphaeridia sp. indet. and Gyalosphaeridium pulchrum from the Dey Dey Mudstone at $230.4 \mathrm{~m}$ in Murnarnoo borehole of northern South Australia are not only large (150-400 and 350-450 $\mu \mathrm{m}$ diameter respectively) but have a chitin composition, brittle fracture, and at least three wall layers (Willman \& Moczydłowska 2007, Willman 2009).
The Dey Dey Mudstone includes dropped pebbles as evidence for glaciation which Gostin et al. (2010) correlate with Gaskiers Glaciation, which in turn is dated by $\mathrm{U}-\mathrm{Pb}$ analysis of zircons in Newfoundland as $582.4 \pm 0.5 \mathrm{Ma}$ to $583.7 \pm 0.5 \mathrm{Ma}$ (van Kranendonk et al. 2008). The Dey Dey Mudstone in nearby boreholes (Munta 1 and Observatory Hill 1) also includes the global Shuram-Wonoka carbon isotopic excursion, correlated by Halverson et al. (2010) and Le Guerroué (2010) with the Gaskiers Glaciation, but better correlated with end of the Fauquier Glaciation with interpolated age of $567 \pm 6 \mathrm{Ma}$ (Retallack et al. 2014). These acritarchs are not unusual for Ediacaran palynomorphs, but have been studied in more detail by TEM and FTIR than most to reveal characteristic fungal features. Additional studies are needed to establish fungal affinities of other acritarchs.

\section{ACRITARCH DIVERSIFICATION RECONSIDERED}

Diversification then decline of the Ediacaran Complex Acanthomorph Palynoflora (ECAP acritarchs) is a remarkable Late Ediacaran biological event (Schopf 1999, Grey, 2005), coincident with rise and decline of the enigmatic Vendobionta (Fig. 5, Table 2). After acritarch and vendobiont mass extinctions at the Cambrian-Precambrian boundary, a diversification of unrelated small acritarchs (Talyzina \& Moczydłowska 2000, Moczydłowska et al. 2011) accompanied the Cambrian explosion of metazoa and metaphytes (Fedonkin et al. 2008, Erwin et al. 2011).

Ediacaran diversification of large acritarchs has been attributed to metazoan diversification, based on interpretation of Vendobionta as metazoans, a limited array of putative metazoan trace fossils, and putative permineralized metazoans and embryos (Gaucher \& Sprechmann 2009, Cohen et al. 2009, Erwin et al. 2011). However, evidence for Ediacaran metazoans is dwindling. A combination of simple morphology and indifferent preservation of most soft-bodied Ediacaran and Cryogenian fossils has compounded the mystery: none can be unequivocally attributed to metazoans (Antcliffe \& Brasier 2008, Antcliffe et al. 2011, Erwin et al. 2011, Meert et al. 2011). Some of these

Table 2. Vendobiont generic diversity curve

\begin{tabular}{lllll}
\hline Assemblage & Age & Ma & Genera & Reference \\
\hline Grindstone Range, South Australia, Australia & early Early Ordovician & $482-488$ & 4 & Retallack 2009 \\
Mosinee, Wisconsin, USA & Late Cambrian & $488-501$ & 1 & Hagadorn et al. 2002 \\
Booley Bay, Ireland & late Middle Cambrian & $501-505$ & 2 & Vanguestaine \& Brück 2005 \\
Burgess Shale, British Columbia, Canada & early Middle Cambrian & $505-513$ & 1 & Conway Morris 1993 \\
Death Valley, California, USA & late Early Cambrian & $513-515$ & 1 & Hagadorn et al. 2000 \\
Chengjiang, Yunnan, China & middle Early Cambrian & $515-525$ & 1 & Shu et al. 2005 \\
Mudlapena Gap, South Australia, Australia & early Early Cambrian & $525-542$ & 2 & Jensen et al. 1998 \\
Nama, Namibia & late late Ediacaran & $542-550$ & 15 & Shen et al. 2008 \\
Ediacara Hills, South Australia, Australia & late Ediacaran & $550-555$ & 77 & Shen et al. 2008 \\
Ferryland, Newfoundland, Canada & late Ediacaran & $555-560$ & 7 & Gehling et al. 2000 \\
Mistaken Point, Newfoundland, Canada & middle Ediacaran & $560-570$ & 30 & Wilby et al. 2011 \\
Ives Head, Leicestershire, England & early middle Ediacaran & $570-600$ & 5 & Boynton \& Carney 2003 \\
Bunyeroo Gorge, South Australia, Australia & early Ediacaran & $600-635$ & 1 & Runnegar \& Fedonkin 1991 \\
Mount Remarkable, South Australia, Australia & late Cryogenian & $635-700$ & 1 & Runnegar \& Fedonkin 1991 \\
Lualobei, Anhui, China & middle Cryogenian & $700-850$ & 1 & Sun et al. 1986; Meert et al. 2011 \\
\hline
\end{tabular}




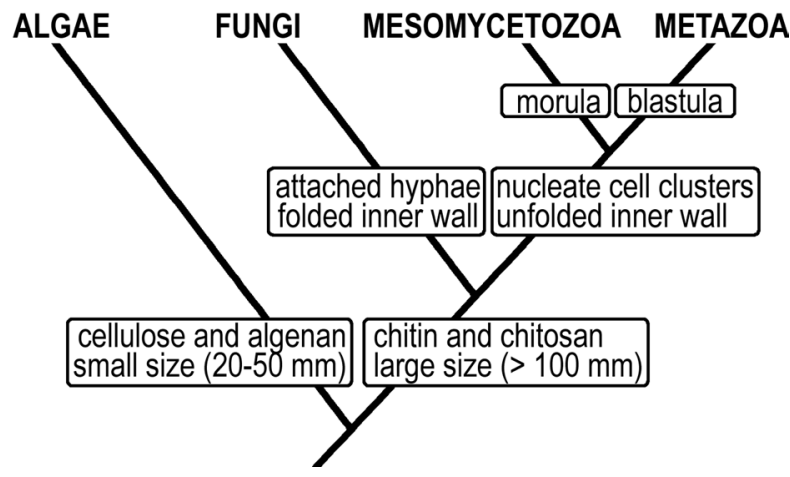

Figure 3 Diagnostic biological features of acritarchs on a simplified phyletic tree

unskeletonized Ediacaran organisms lived on dry land (Retallack 2013 a). Skeletonized and phosphatic Cryogenian and Ediacaran fossils including Cloudina and Corumbella are more convincing as animals, but difficult to assign to modern animal groups (Fedonkin et al. 2008, Maloof et al. 2010). Non-penetrative trace fossils (Pecoits et al. 2012, Chen et al. 2013) could have been the work of slug-aggregating phases of amoeboid organisms, such as slime molds (Bengtson et al. 2007, Retallack 2012, 2013b). In other cases, supposed trails (Liu et al. 2010a, 2010b) appear to be tool marks (Retallack 2010). Supposed Ediacaran animal embryos in acritarchs from the Doushantou Formation at Weng'an may have been giant sulfur bacteria (Bailey et al. 2007) or mesomycetozoans (Huldtgren et al. 2011), rather than metazoans. Although the embryo interpretation remains defensible with contraindications explained by taphonomic artefacts (Xiao et al. 2012, Schiffbauer et al. 2012, Yin et al. 2013), there has not yet been found a convincing Ediacaran embryo like those from Cambrian phosphorites (Zhang et al. 2011). A putative permineralized metazoan ("Vernanimalcula guizhouensis") also from Weng'an appears to be mineralized vugs (Bengtson et al. 2012, Petryshyn et al. 2013). This leaves only biomarker (Love et al. 2009) and skeletal (Maloof et al. 2010) evidence for Cryogenian (635-713 Ma) organisms of sponge grade. Gemmules of sponges, listed as plausible acritarchs by Cohen et al. (2009), are spiculate fossils (Harrison \& Warner 1986), unlike most Precambrian acritarchs.

Ediacaran diversification of large acritarchs (Fig. 5 C) and Vendobionta (Fig. 5 B) may reflect mostly diversification of Glomeromycota and Mucoromycotina, rather than giant sulfur bacteria, Mesomycetozoa or Metazoa. Cambrian diversification of small spiny acritarchs of modern appearance, on the other hand, may represent the rise of phytoplankton and metazoan resting phases (Cohen et al. 2009, Moczydłowska et al. 2011) fuelling the Cambrian explosion of small shelly fossils and most modern marine invertebrate phyla (Erwin et al. 2011). Acritarchs were diverse, like other palynomorphs, and a simplified guide to their affinities is presented in Fig. 3. By all likely affinities Proterozoic acritarchs were broadcast propagules, like other palynomorphs, finding their way from, and into, marine, freshwater and terrestrial habitats (Strother et al. 2011). Proterozoic acritarchs like vendobionts (Retallack 2013a, 2014) can no longer be assumed to have been entirely marine.

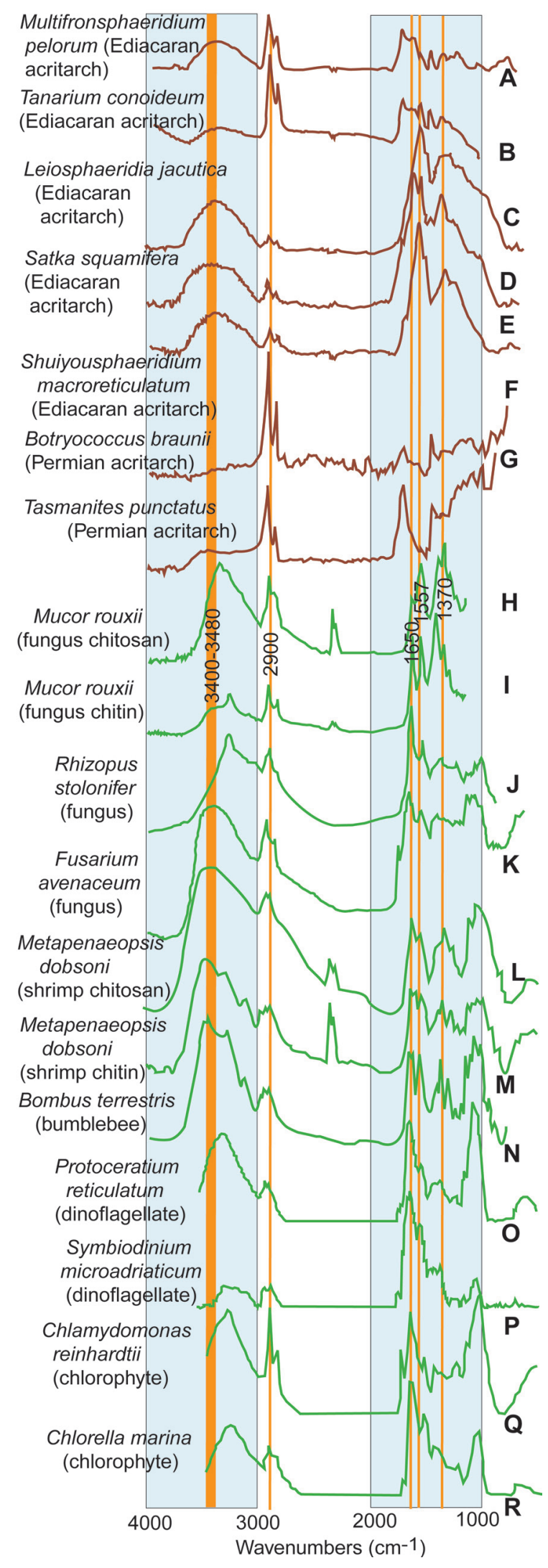

Figure 4 FTIR spectra of acritarchs (A-F) and a range of comparable modern organisms (G-Q). Ediacaran acritarchs (A-D) have spectra comparable with chitin and chitosan of fungi, shrimp and bees $(\mathrm{H}-\mathrm{N})$, distinct from the composition of Paleozoic acritarchs $(\mathrm{E}-\mathrm{F})$ and modern phytoplankton (O-Q). Vertical lines are characteristic chitin and chitosan absorption bands (Wu et al 2005) at 1370, 1557, 1650, 2900 and $3400-3480 \mathrm{~cm}^{-1}$. Sources of spectra are in Table 1 
Ediacaran Stratotype

A. Formation Lithology Grain size

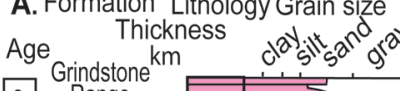

Grindstone

o. Sandston

z 3 Pantapinna ${ }^{9}$

Sandstone
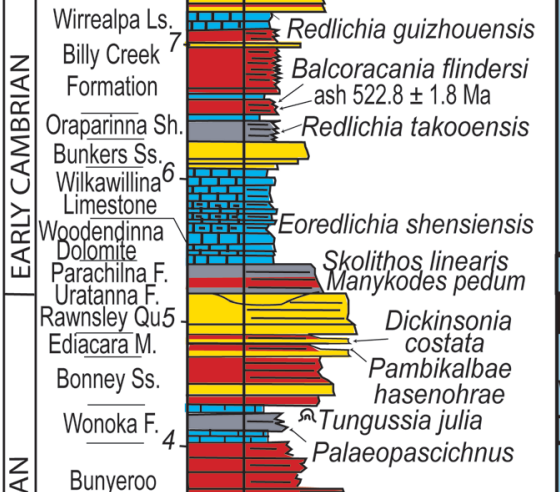
Formation

\section{$\overline{A B C}$
Quartzite}

Brachina

Formation

$z$ Trezona $F$.

$\lesssim$ Enorama F.

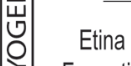

Formation

\section{a b c d ef $g \square h$ 四}

\section{Global Diversity}

B.Vendobionts C. Acritarchs genera (number) species (number)

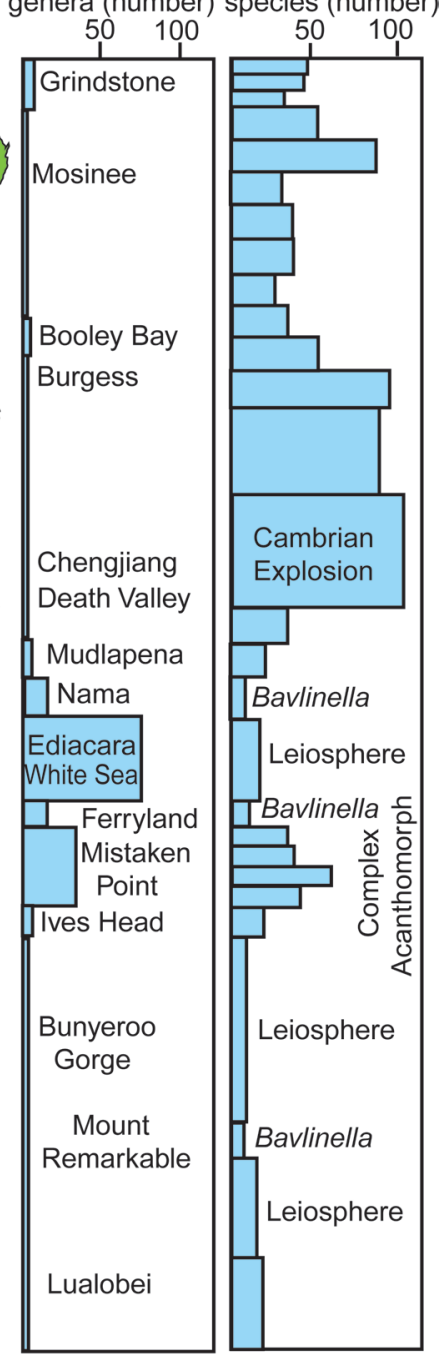

Figure 5 Ediacaran stratotype section in South Australia (A) and global diversity of Vendobionta (B) and acritarchs (C) (see Tables 2 and 3 for sources). Lithological groups: $\mathrm{a}$ - pink sandstone, $\mathrm{b}$ - red sandstone, $\mathrm{c}-$ red siltstone, $\mathrm{d}-$ white sandstone, $\mathrm{e}$ - light-gray limestone, $\mathrm{f}$ - dark-gray shale, $\mathrm{g}$ - clastic, $\mathrm{h}$ - carbonate

Acritarchs regarded here as records of Mesoproterozoic Glomeromycota agree with a fungal molecular clock pushing the fungus-animal split back $2200 \mathrm{Ma}$ based on nucleotide substitution of 50 genes (Taylor \& Berbee 2006), pegged to the sordariomycete ascomycotan Paleopyrenomycites devonicus from the early Devonian Rhynie Chert of Scotland (Taylor et al. 2005). This clock is compatible with the likely Archaeosporalean glomeromycotan Diskagma buttonii from the $2200 \mathrm{Ma}$ Waterval Onder paleosol of South Africa (Retallack et al. 2013a), probable siphoneous green algae Grypania spiralis from the $1874 \mathrm{Ma}$ Negaunee Iron Formation of Michigan (Han \& Runnegar 1991, Schneider et al. 2002), the first appearance of trilobites at $521 \mathrm{Ma}$ (Hollingsworth 2008) and well preserved glomeromycotan spores at $449 \mathrm{Ma}$ (Redecker et al. 2000). Other molecular clocks have the fungus-animal spit at about $1600 \mathrm{Ma}$ (Heckman et al. 2001, Bhattacharya et al. 2009), 1200-820 Ma (Lücking et al. 2009) and $950 \mathrm{Ma}$ (Berbee \& Taylor 2010). Molecular clock ages remain uncertain, but all trees cited here demonstrate an early divergence of Glomeromycota and Mucoromycotina, well before Basidiomycota and Ascomycota. The lack of ascospores and basidiospores in Precambrian palynological preparations is striking (Strother et al. 2011). A plausible ascus from the $790 \mathrm{Ma}$ Skillogalee Dolomite of South Australia (Schopf \& Barhgoorn 1969, Preiss et al. 2009) has been reinterpreted as an intercalary oogonium of a water mold (Saprolegniales, Oomycota) by Pirozynski (1976).

\section{MYCOTROPHIC HYPOTHESIS EMENDED}

The hypothesis presented here of diverse Ediacaran Glomeromycota has implications for the mycotrophic ("fungal feeding") hypothesis of Jeffrey (1962). The mycotrophic hypothesis was more fully fleshed out by Pirozynski \& Malloch (1975), who proposed that plant colonization of land required nutrition from fungal mycorrhizae. Glomalean fungi of the phylum Glomeromycota are essential for nutrient acquisition on land as mycorrhizal symbionts of most vascular land plants (Malloch et al. 1980, Wang \& Qiu 2006), and many bryophytes (Ligrone et al. 2007). Two minor aspects of their original hypothesis are now problematic. First, Pirozynski \& Malloch (1975) argued that Oomycota were the essential fungal partner, but mycorrhizal fungi (Glomales, Glomeromycota: Hibbett et al. 2007) have now been segregated from Oomycota (water molds, such as Phytophora cinnamoni), which are not Fungi, but Heterokonta (Cavalier-Smith 2006). Second, Pirozynski \& Malloch (1975) and Jeffrey (1962) both linked their hypothesis to the idea that multicellular aquatic green algae colonized the land. Stebbins \& Hill (1980) have argued that archegoniate land plants evolved from fully terrestrial small soil algae, with three dimensional thalli and conjugation rather than zoospores. Conjugation and fungal mycotrophism are more effective on land than in water (Hawksworth 2000), and this is accepted here as a useful amendment to the mycotrophic hypothesis. With these caveats, the core concept of the mycotrophic hypothesis that land was prepared for plants by fungi is now supported by likely Proterozoic glomeromycotan-mucoromycotan acritarchs (Figs. 1-4) and other fossils (Retallack et al. 2013a, 2013b), and a Paleozoic fossil record of Glomalean fungi before land plants (Pirozynski 1976, Pirozynski \& Dalpé 1989, Redecker et al. 2000). Diskagma (Retallack et al. 2013a), Horodyskia (Retallack et al. 2013b), and Tappania (Butterfield 2005) may have been free-living glomeromycotans in loose association with cyanobacterial mats, predicted as hypothetical organisms by Sherwood-Pike (1991).

Four other lines of support for the mycotrophic hypothesis also postdate its elaboration by Pirozynski \& Malloch (1975). First, Archaeosporales are a group of free living soil 
Table 3. Acritarch specific diversity curve

\begin{tabular}{|c|c|c|c|c|}
\hline Acritarch assemblages & Age & $\mathrm{Ma}$ & Spp. & Reference \\
\hline Cymatiogalea messaoudensis & early Migneintan & $482-484$ & 49 & Vecoli \& Le Hérissé 2004 \\
\hline Cymatiogalea messaoudensis & late Cressagian & $484-488$ & 48 & Vecoli \& Le Hérissé 2004 \\
\hline Acanthodiacrodium angustum & early Cressagian & $486-488$ & 37 & Vecoli \& Le Hérissé 2004 \\
\hline Izhoria angulata & UC6 & $488-490$ & 54 & Vidal \& Moczydłowska 1997, Raevskaya 2005 \\
\hline Impluviculus villosiuculus & UC5 & $490-492$ & 86 & Vidal \& Moczydłowska 1997, Raevskaya 2005 \\
\hline Trunculumarium revinium & UC4 & $492-494$ & 30 & Vidal \& Moczydłowska 1997, Raevskaya 2005 \\
\hline Impluliviculus multiangularis & UC3 & $494-496$ & 37 & Vidal \& Moczydłowska 1997, Raevskaya 2005 \\
\hline Cymatiogalea spp. & UC2 & $496-498$ & 37 & Vidal \& Moczydłowska 1997, Raevskaya 2005 \\
\hline Timofeevia pentagonalis & UC1 & $498-501$ & 27 & Vidal \& Moczydłowska 1997, Raevskaya 2005 \\
\hline Timofeevia phosphoritica & P. forchammeri & $501-504$ & 33 & Vidal \& Moczydłowska 1997, Raevskaya 2005 \\
\hline Cristallinium cambriense & P. paradoxisiumus & $504-507$ & 54 & Vidal \& Moczydłowska 1997, Raevskaya 2005 \\
\hline Baltisphaeridium pseudofaveolatum & A. oelandi & $507-510$ & 93 & Vidal \& Moczydłowska 1997, Raevskaya 2005 \\
\hline Volkovia-Liepania & Protolenus & $510-512$ & 86 & Vidal \& Moczydłowska 1997, Raevskaya 2005 \\
\hline Heliosphaeridium-Skiagia & Holmia igerulfi & $512-525$ & 102 & Vidal \& Moczydłowska 1997, Raevskaya 2005 \\
\hline Skiagia-Fimbriaglomerella & Schmidtiella & $525-534$ & 36 & Vidal \& Moczydłowska 1997, Raevskaya 2005 \\
\hline Asteridium-Compaesphaeridium & Platysolenites & $534-542$ & 22 & Vidal \& Moczydłowska 1997, Raevskaya 2005 \\
\hline Bavlinella faveolata (LELP crisis) & Late Ediacaran & $542-550$ & 9 & Gaucher \& Sprechmann 2009 \\
\hline Trachysphaeridium partiale & Late Ediacaran & $550-555$ & 14 & Leonov \& Ragozina 2007 \\
\hline Bavlinella faveolata (LELP crisis) & Late Ediacaran & $555-560$ & 9 & Gaucher \& Sprechmann 2009 \\
\hline Ceratosphaeridium mirabile ECAP & Middle Ediacaran & $560-565$ & 30 & Grey 2005 \\
\hline Tanarium irregulare (ECAP) & Middle Ediacaran & $565-570$ & 32 & Grey 2005 \\
\hline Tanarium conoideum (ECAP) & Middle Ediacaran & $570-575$ & 48 & Grey 2005 \\
\hline Appendisphaera barbata (ECAP) & Middle Ediacaran & $575-580$ & 33 & Grey 2005 \\
\hline Leiosphaeridia spp. (EELP) & Early Ediacaran & $590-610$ & 15 & Gaucher \& Sprechmann 2009 \\
\hline Leiosphaeridia spp. (EELP) & Early Ediacaran & $610-635$ & 11 & Gaucher \& Sprechmann 2009 \\
\hline Bavlinella faveolata (crisis) & Late Cryogenian & $635-675$ & 10 & Gaucher \& Sprechmann 2009 \\
\hline Papillomembrana-Ericiasphaera & Late Cryogenian & $675-700$ & 17 & Gaucher \& Sprechmann 2009 \\
\hline Papillomembrana-Ericiasphaera & mid-Cryogenisn & $700-740$ & 21 & Gaucher \& Sprechmann 2009 \\
\hline Bavlinella faveolata (crisis) & mid-Cryogenisn & $740-765$ & 11 & Gaucher \& Sprechmann 2009 \\
\hline Simia-Cerebrosphaera & Early Cryogenian & $765-820$ & 41 & Gaucher \& Sprechmann 2009 \\
\hline Simia-Cerebrosphaera & Early Cryogenian & $820-840$ & 33 & Gaucher \& Sprechmann 2009 \\
\hline Simia-Cerebrosphaera & Early Cryogenian & $840-930$ & 15 & Gaucher \& Sprechmann 2009 \\
\hline Simia-Cerebrosphaera & Early Cryogenian & $930-1200$ & 11 & Gaucher \& Sprechmann 2009 \\
\hline
\end{tabular}

glomeromycotans represented by Geosiphon pyriforme, which has a large vesicle to contain the endosymbiotic cyanobacterium Nostoc punctiforme (Schüßler et al. 1994, Schüßler 2012). Thus not all glomeromycotan fungi are dependent on vascular plant roots.

Second, studies of ecological succession in western North American desert soil crusts show the following stages: 1, bare soil; 2, large filamentous cyanobacteria such as Microcoleus vaginatus; 3 , gelatinous lichens such as Collema coccophorum; 4, squamulose lichens such as Psora cerebriformis; 5, crustose lichens such as Diploschistes scruposus; 6, liverworts such as Cephaloziella divaricata; 7 , short mosses such as Bryum argenteum; 8, foliose lichens such as Xanthoparmelia convoluta; 9, tall mosses such as Syntrichia ruralis; 10, fruticose lichens such as Aspicilia filiformis; 11, early successional angiosperms such as Chrysothamnus nauseus, and 12, late successional angiosperms such as Artemisia tridentata (Rosentreter 1984, Belnap et al. 2001). Current ecological succession may be recapitulating Precambrian communities of lichens and microbes on land (Retallack 2012), with cyanobacterial stage 2 reached very early in Earth history, lichen stage 3 by the Proterozoic, non-vascular land plant stage 6 by Ordovician (Katian), and the vascular plant stage 11 by Silurian
(Wenlockian: Retallack 2001, Retallack et al. 2013a).

Third, free living lichens, in which cyanobacterial phycobionts are enclosed by glomeromycotan-mucoromycotinan hyphae, are represented by an un-named permineralized fossil from the Doushantou Formation near Weng'an, China (Yuan et al. 2005). Thus glomeromycotan-mucoromycotinan fungi included extinct forms of lichens constructed in a manner comparable with familiar ascolichens and basidiolichens (Honegger et al. 2013, Matsunaga et al. 2013), in addition to likely endosymbiotic forms such as Diskagma (Retallack et al. 2013a), and Horodyskia (Retallack et al. 2013b).

Fourth, paleosols of Ordovician to Paleoproterozoic ages show evidence of life on land from chemical depletion of phosphorus and cationic nutrients $\left(\mathrm{Ca}^{2+}, \mathrm{Mg}^{2+}, \mathrm{Na}^{+}\right.$, $\mathrm{K}^{+}$) and filamentous bioturbation comparable with, though less intense than, modern soils (Retallack 2008, 2009, 2011, 2013a, Retallack et al. 2013a). Many of these paleosols were calcareous and fertile, but some were quartzose and infertile substrates (Retallack 2009, 2013a) insufficiently organic to support large populations of unlichenized fungi. Some of these paleosols supported vendobiont fossils with lichenlike features such as indeterminate growth, compaction resistant biopolymers and tubular-fractal construction 
(Retallack 2007, 2013a). The Paleoproterozoic (2200 Ma) fossil Diskagma buttonii may be the oldest Glomeromycotan fungus, and was found in a Vertisol paleosol formed under a moderately oxidizing atmosphere and cool temperate paleoclimate (Retallack et al. 2013a). Latest Archean (2600 Ma) Eomycetopsis may represent even older Glomeromycota from stromatolitic (thus aquatic) cherts (Altermann \& Schopf 1995). Eomycetopsis is a tubular microfossil named for its close similarity with fungal hyphae (Schopf 1968), but subsequently reinterpreted as cyanobacterial sheaths because aseptate (Knoll 1982). This objection to assigning Eomycetopsis to Ascomycota or Basidiomycota does not apply to Glomeromycota, which are mainly aseptate (Hibbett et al. 2007, Moore 2013).

Theories of lichen evolution unsupported by the fossil record include the ascophyte hypothesis of Cain (1972) and the protolichen hypothesis of Eriksson (2005), which both address ascomycotan evolution. Cain (1972) envisaged ascomycotans as fundamentally terrestrial and derived from photosynthetic red algae that lived on land. Eriksson (2005) proposed that higher ascomycotans (Pezizomycotina) were derived from lichens rather than saprobes. These views are countered by a recent phylogenetic tree showing that ancestral ascomycotans were saprophytic rather than lichenized or free living (Schoch et al. 2009). Both views are also countered by lack of evidence for ascomycotan fossils older than vascular land plants of Late Silurian age (425 Ma (Sherwood-Pike \& Gray 1985, Burgess \& Edwards 1991, Taylor et al. 2014). The Early Devonian (400 Ma) Rhynie Chert of Scotland has yielded secure records of saprophytic chytrids and oomycotans, mycoparasitic chytrids, phytoparasitic chytrids and pyrenomycete ascomycotans, glomalean arbuscular endomycorrhizae, and mucoromycotinan lichens (Taylor \& Taylor 2000, Taylor et al. 2005, 2014). The Early Devonian Ditton Group of Wales has yielded ascomycotan and basidiomycotan lichens (Honegger et al. 2013).

\section{CONCLUSIONS}

Large Proterozoic acritarchs such as Tappania, Leiosphaeridia, Gyalosphaeridium, Ceratosphaeridium and Germinosphaera (Grey 2005, Butterfield 2005), with hyphae and chitinous multi-layered walls are here regarded as Glomeromycotan fungal chlamydospores and vesicles, confirming glomeromycotan-mucoromycotinan affinities of an un-named Ediacaran permineralized lichen (Yuan et al. 2005), Mesoproterozoic Horodyskia (Retallack et al. 2013b) and Paleoproterozoic Diskagma (Retallack et al. 2013a). Glomeromycotan, rather than ascomycotan or basidiomycotan, affinities are thus more likely for Ediacaran impression fossils considered fungal, such as Dickinsonia (Retallack 2007, 2013) and Fractifusus (Peterson et al. 2003, Gehling \& Narbonne 2007). Considering lack of unequivocal Ediacaran metazoan fossils (Bengtson et al. 2007, 2012, Huldtgren et al. 2011, Petryshyn et al. 2012), other than sponges which have distinctive gemmules (Harrison \& Warner 1986), late Ediacaran diversification of large acritarchs may have been an evolutionary event mainly involving fungi. The Paleoproterozoic appearance of glomeromycotan fungi
(Retallack et al. 2013a) also supports a glomeromycotan mycotropic (Pirozynski \& Malloch 1975) and terrestrial (Stebbins \& Hill 1980) origin of Early Paleozoic land plants. Glomeromycota still secure the nutrition of most land plants as symbiotic mycorrhizal associations (Wang \& Qiu 2006), and may have been essential to the nutrition of early land plants and subsequently of primitively saprophytic higher fungi such as Basidiomycota and Ascomycota (Schoch et al. 2009).

\section{ACKNOWLE D G M E N T S}

Yolande Dalpé, Chiguang Wu, Sebastian Willman and Kathleen Grey graciously supplied photographs. Discussions with Phil Donoghue, Jake Bailey and Stefan Bengtson, and reviews by Sebastian Willman and Kathleen Grey are gratefully acknowledged. This work was partially funded by University of Oregon Academic Support.

\section{LITERATURE CITED}

Ali, A.M.M., T. Kawasaki \& T. Yamada 2007. Characterization of a chitinase gene encoded by virus-sensitive Chlorella strains and expressed during virus infection. Arab Journal of Biotechnology 10:81-96.

Altermann, W. \& J.W. Schopf 1995. Microfossils from the Neoarchean Campbell Group, Griqualand West Sequence of the Transvaal Supergroup, and their paleoenvironmental and evolutionary implications. Precambrian Research 75:65-90.

Antcliffe, J.B. \& M.D. Brasier 2008. Charnia at 50: developmental models for Ediacaran fronds. Palaeontology 51:11-26.

Antcliffe, J.B., A.J. Gooday \& M.D. Brasier 2011. Testing the protozoan hypothesis for Ediacaran fossils: a developmental analysis of Palaeopascichnus. Palaeontology 54:1157-1175.

Arouri, K., P.F. Greenwood, \& M.R. Walter. 1999. A possible chlorophycean affinity of some Neoproterozoic acritarchs. Organic Geochemistry 30:1323-1337.

Arouri, K., P.F. Greenwood \& M.R. Walter 2000. Biological affinities of Neoproterozoic acritarchs from Australia: microscopic and chemical characterization. Organic Geochemistry 31:75-89.

Bailey, J.V., S.B. Joye, K.M. Kalanetra, B.E. Flood \& F.A. Corsetti 2007. Evidence of giant sulphur bacteria in Neoproterozoic phosphorites. Nature 445:198-201.

Barfod, G.H., F. Albarède, A.H. Knoll, S. Xiao, P. Télouk, R. Frei \& J. Baker 2002. New Lu-Hf and Pb-Pb age constraints on the earliest animal fossils. Earth \& Planetary Science Letters 201:203-212.

Bartnicki-Garcia, S. 1968. Cell wall chemistry, morphogenesis and taxonomy of Fungi. Annual Reviews of Microbio$\log y$ 22:87-108.

Belnap, J., J.H. Kaltenecker, R. Rosentreter, J. Williams, S. Leonard \& D. Eldridge 2001. Biological soil crusts: ecology and management. Bureau of Land Management Technical Reference 1730 2:1-110.

Bengtson, S., B. Rasmussen \& B. Krapež 2007. The Palaeoproterozoic megascopic Stirling biota. Paleobiology 33:71120.

Bengtson, S., J.A. Cunningham, C. Yin \& P.C.J. Donoghue 2012. A merciful death for "the earliest bilaterian" Vernanimalcula. Evolution and Development 14:421-427.

Berbee, M.L. \& J.W. Taylor 2010. Dating the molecular clock in fungi - how close are we? Fungal Biology Reviews 24:1-16. 
Bever, J.D. \& M. Wang 2005. Arbuscular mycorrhizal fungi: hyphal fusion and multigenomic structure. Nature 433:E3-E4.

Bhattacharya, D., H.S. Soon, S.B. Hedges \& J.D. Hackett 2009. Eukaryotes (Eukaryota). In: The timetree of life (S.B. Hedges \& S. Kumar, eds.), pp. 116-120. Oxford Univ. Press, New York.

Blair, J.E. 2009. Fungi. In: The timetree of life (S.B. Hedges \& S. Kumar, eds.), pp. 215-219. Oxford Univ. Press, New York.

Bonfante-Fasolo, P. \& A. Schubert 1987. Spore wall architecture of Glomus spp. Canadian Journal of Botany 65:539-546.

Bowers, B. \& E.D. Korn 1969. The Fine Structure of Acanthamoeba castellanii (Neff Strain). II. Encystment. Journal of Cell Biology 41:786-805.

Boynton, H. \& J. Caney 2003. Field excursion to the Precambrian fossil localities at Ives Head and Bradgate Park, Charnwood Forest. British Geological Survey Occasional Publication 3:1-20.

Bristow, T.F., M.J. Kennedy, A. Derkowski, M.L. Droser, G. Jiang \& R.A.Creaser 2009. Mineralogical constraints on the paleoenvironments of the Ediacaran Doushantuo Formation. U.S. National Academy of Sciences Proceedings 106:13190-13195.

Burgess, N.D. \& D. Edwards 1991. Classification of uppermost Ordovician to lower Devonian tubular and filamentous macerals from the Anglo-Welsh Basin. Botanical Journal Linnaean Society 106:41-66.

Burzin, M.B. 1993. The oldest chytrid (Mycota, Chytridiomycetes incertae sedis) from the upper Vendian of the East European Platform. In: Fauna and ecosystems of the geological past (B.S. Sokolov, ed.), pp. 21-33. Nauka, Moskva (in Russian). [Бурзин М.Б. Аревнейший хитридиомицет (Mycota, Chytridiomycetes incertae sedis) из верхнего венда Восточно-Европейской платформы // Фауна и экосистемы геологического прошлого / поА реА. Б.С. Соколова. Москва: Наука. С. 21-33].

Butterfield, N.J. 2005. Probable Proterozoic fungi. Paleobio$\log y$ 31:165-182.

Butterfield, N.J. \& R.H. Rainbird 1998. Diverse organic walled microfossils, including "possible dinoflagellates," from the early Neoproterozoic of arctic Canada. Geology 26:963-966.

Cain, R. 1972. Evolution of the Fungi. Mycologia 64:1-14.

Calderón, F.J., V. Acosta-Martinez, D.D. Douds, J.B. Reeves $\&$ M.F. Vigil 2009. Mid-infrared and near-infrared spectral properties of mycorrhizal and non-mycorrhizal root cultures. Applied Spectroscopy 63:494-500.

Cavalier-Smith, T. 2006. Cell evolution and Earth history: stasis and revolution. Royal Society of London Philosophical Transactions B362:969-1006.

Chen, Z., C. Zhou, M. Meyer, X. Xiang, J.D. Schiffbauer, X. Yuan \& S. Xiao 2013. Trace fossil evidence for Ediacaran bilaterian animals with complex behaviors. Precambrian Research 224:690-701.

Cohen, P.A., A.H. Knoll \& R.B. Kodner 2009. Large spinose microfossils in Ediacaran rocks as resting stages of early animals. U.S. National Academy of Sciences Proceedings 106:6519-6524.

Colbath, G.K. 1983. Fossil prasinophycean phycomata (Chlorophyta) from the Silurian Bainbridge Formation, Missouri, U.S.A. Phycologia 22:249-265.

Condon, D., M. Zhu, S. Bowring, W. Wang, A.Yang \& Y. Jin 2005. U-Pb ages from the Neoproterozoic Doushantuo Formation, China. Science 308:95-98.
Conway Morris, S. 1993. Ediacaran-like fossils in Cambrian Burgess Shale-type faunas of North America. Palaeontology 36:593-635.

Domenighini, A. \& D.M. Giordano 2009. Fourier transform infrared spectroscopy of microalgae as a novel tool for biodiversity studies, species identification, and the assessment of water quality. Journal of Phycology 45:522-531.

Eriksson, O.E. 2005. Origin and evolution of Ascomycota - The protolichenes hypothesis. Svensk Mycologische Tidskrifft 26:30-33.

Erwin, D.H., M. La Flamme, S.M. Tweedt, E.A. Sperling, D. Pisani \& S.K. Peterson 2011. The Cambrian conundrum: early divergence and later ecological success in the history of animals. Science 344:1091-1097.

Fedonkin, M.A., J.G. Gehling, K. Grey, G.M. Narbonne \& P. Vickers-Rich (eds.) 2008. The rise of animals: evolution and diversification of the Kingdom Animalia. Johns Hopkins University Press, Baltimore, 344 pp.

Gaucher, C. \& P. Sprechmann 2009. Neoproterozoic acritarch evolution. In Neoproterozoic-Cambrian tectonics, global change and evolution: a focus on southwestern Gondwana (C. Gaucher, A.N. Sial, G.P. Halvorson \& H.E. Frimmel, eds.), pp. 319-326. Elsevier, Amsterdam.

Gehling, J.G. \& G.M. Narbonne 2007. Spindle-shaped Ediacara fossils from the Mistaken Point assemblage, Avalon Zone, Newfoundland. Canadian Journal of Earth Sciences 44:367-387.

Gehling, J.G., G.M. Narbonne \& M.M. Anderson 2000. The first named Ediacaran body fossil; Aspidella terranovica. Palaeontology 43:427-456.

Gostin, V.A., D.M. McKirdy, L.J. Webster \& G.E. Williams 2010. Ediacaran ice-rafting and coeval asteroid impact, South Australia: insights into the terminal Proterozoic environment. Australian Journal of Earth Science 57:859-869.

Gradstein, F.M., J.G. Ogg, M.D. Schmitz \& G.M. Ogg 2012. The geologic time scale 2012, vol. 1. Elsevier, Amsterdam, $1176 \mathrm{pp}$.

Grey, K. 2005. Ediacaran palynology of Australia. Association of Australasian Palaeontologists Memoir 31:1-439.

Grey, K. \& S. Willman 2009. Taphonomy of Ediacaran acritarchs from Australia: significance for taxonomy and biostratigraphy. Palaios 24:239-256.

Hagadorn, J.W., C.M. Fedo \& B.M. Waggoner 2000. Early Cambrian Ediacaran-type fossils from California. Journal of Paleontology 74:731-740.

Hagadorn, J.W., R.H. Dott \& D. Damrow 2002. Stranded on an Upper Cambrian shoreline: medusae from central Wisconsin. Geology 30:147-150.

Halverson, G.P., B.P. Wade, M.T. Hurtgen \& K.M. Barovich 2010. Neoproterozoic chemostratigraphy. Precambrian Research 182:337-350.

Han, T.-M. \& B. Runnegar 1992. Megascopic eukaryotic algae from the 2.1-billion-year-old Negaunee Iron-Formation. Science 257:232-235.

Harrison, F.W. \& B.G. Warner 1986. Fossil fresh-water sponges (Porifera: Spongillidae) from Western Canada: an overlooked group of Quaternary paleoecological indicators. American Microscopical Society Transactions 105:110-120.

Hawksworth, D.L. 2000. Freshwater and marine lichenforming fungi. In: Aquatic mycology across the millennium (K.D. Hyde, W.H. Ho \& S.B. Pointing, eds.). Fungal Diversity $5: 1-7$.

Hawksworth, D. \& R. Honegger 1994. The lichen thallus: a symbiotic phenotype of nutritionally specialized fungi and its response to gall producers. In: Plant galls - organisms, interactions, populations (M.A.J. Williams, ed.), pp. 77- 
98. Systematics Association Special Volume, Clarendon Press, Oxford.

Heckman, D.S., D.M. Geiser, B.R. Eidell, R.L. Stauffer, N.L. Kardos \& S.B. Hedges 2001. Molecular evidence for the early colonization of land by fungi and plants. Science 293:1129-1134.

Helbert, W., M. Ishihara \& S. Yamanaka 1997. Characterization of native crystalline cellulose in the cell walls of Oomycota. Journal of Food Biotechnology 57:29-37.

Hermann, T.N. 1979. Discoveries of fungi in the Riphean. In: Paleontology of the Precambrian and lower Cambrian (B.S. Sokolov, ed.), pp. 129-136, Nauka, Leningrad (in Russian). Герман Т.Н. 1979. Находки грибов в рифее // Памеонтология докембрия и раннего кембория / поА реА. Б.С. Соколова. Аенинград: Наука. С. 129-136.

Herth, W., A. Kippel \& E. Schnepf 1977. Chitinous fibrils in the lorica of the flagellate Poterochromonas stipitata (syn. Ochromonas malhamensis). Journal of Cell Biology 73:311-321.

Hibbett, D.S., B. Binder, J.F. Bischoff, M. Blackwell, P.F. Cannon, O.E. Erikkson, S. Huhndorf, T. James, P.M. Kirk, R. Lücking, T.H. Lumbsch, F. Lutzoni, P.B. Matheny, D.J. McLaughlin, M.J. Powell, S. Redhead, C.L. Schoch, J.W. Spatafora, J.A. Stalpers, R. Vilgalys, M.C. Aime, A. Aptroot, R. Bauer, D. Begerow, G.L. Benny, L.A. Castlebury, P.W. Crousi, Y.-C Dai, W. Gamsi, D.M. Geiser, G.W. Griffith, C. Gueidan, D.L. Hawksworth, G. Hestmwark, K. Hosaka, R.A. Humber, K.D. Hyde, J.E. Ironside, U. Kõljalg, C.P. Kurtzmann, K.H. Larsson, R. Lichtwardt, J. Longcore, J. Miądlikowskia, A. Miller, J.-M. Moncalvo, S. Mozley-Standridge, F. Oberwinkler, E. Parmasto, V. Reeb, J.D. Rogers, C. Roux, L. Ryvarden, J.P. Sampaio, A. Schüßler, J. Sugiyama, R.G. Thorn, L. Tibell, W.A.Untereiner, C. Walker, Z. Wang, A. Weir, M. Weiss, M.M. White, K. Winka, Y.J. Ya \& N. Zhang 2007. A higher-level phylogenetic classification of the Fungi. Mycological Research 111:509-547.

Hollingsworth, J.S. 2008. The first trilobites in Laurentia and elsewhere. In: Advances in trilobite research (I. Rábano, R. Gonzalo \& D. García-Bellido, eds.), 9: 171-184. Cuadrado del Museo Geominero, Instituta Geológico y Mineria España, Madrid.

Honegger, R., D. Edwards \& L. Axe 2013. The earliest records of internally stratified cyanobacterial and algal lichens from the Lower Devonian of the Welsh Borderland. New Phytologist 197:264-275.

Huldtgren, T., J.A. Cunningham, C. Yin, M. Stampanoni, F. Marone, P.C.J. Donoghue \& S. Bengtson 2011. Fossilized nuclei and germination structures identify Ediacaran "animal embryos" as encysting protists. Science 334:1696-1699.

Javaux, E. 2007. The early eukaryotic fossil record. In: Eukaryotic membranes and cytoskeleton, origin and evolution (G. Jéléky, ed.), pp. 2-17. Landes Bioscience, Austin.

Javaux, E.J., A.H. Knoll \& M.R. Walter 2001. Morphological and ecological complexity in early eukaryotic ecosystems. Nature 412:66-69.

Javaux, E.J., A.H. Knoll \& M.R. Walter 2004. TEM evidence for eukaryotic diversity in mid-Proterozoic oceans. Geobiology 2:121-132.

Javaux, E.J., C.P. Marshall \& A. Bekker 2010. Organic-walled microfossils in 3.2-billion-year-old shallow marine siliciclastic deposits. Nature 463:934-938.

Jeffrey, C. 1962. Origin and differentiation of the archegoniate land-plants. Botanical Notices 115:446.

Jensen, S., J.G. Gehling \& M.L. Droser 1998. Ediacara-type fossils in Cambrian sediments. Nature 393:567-569.

Jones, D.S., A.C. Maloof, M.T. Hurtgen, R.H. Rainbird \&
D.P. Schrag 2010. Regional and global chemostratigraphic correlation of the early Neoproterozoic Shaler Supergroup, Victoria Island, northwestern Canada. Precambrian Research 181:43-63.

Kaminskyj, S., K. Jilkine, A. Szegalmi \& K. Gough 2008. High spatial resolution analysis of fungal cell biochemistry, bridging the analytical gap using synchrotron FTIR spectromicroscopy. FEMS Microbiology Letters 284:1-8.

Kaonongbua, W., J.B. Morton \& J.D. Bever 2010. Taxonomic revision transferring species in Kuklospora to Acaulospora (Glomeromycota) and a description of Acaulospora colliculosa sp. nov. from field collected spores. Mycologia 102:1497-1509.

Kawasaki, T., M. Tanaka, M. Fujie, S. Usami, K. Sakai \& T. Yamada 2002. Chitin synthesis in chlorovirus CVK2infected Chlorella cells. Virology 302:123-131.

Knoll, A.H. 1982. Microfossils from the Late Precambrian Draken Conglomerate, Ny Friesland, Svalbard. Journal of Paleontology 56:755-790.

Koske, R.E. \& J.N. Gemma 1995. Scutellospora hawaïensis: a new species of arbuscular mycorrhizal fungus from $\mathrm{Ha}$ waii. Mycologia 87:678-683.

Koske, R.E. \& C. Walker 1986. Glomus globiferum: a new species of Endogonaceae with a hyphal peridium. Mycotaxon $26: 133-142$

Kralik, M. 1982. Rb/Sr age determinations on Precambrian carbonate rocks of the Carpentarian McArthur Basin, Northern Territory, Australia. Precambrian Research 18:157-170.

Le Guerroué, E. 2010. Duration and synchroneity of the largest negative carbon isotope excursion on Earth: the Shuram/Wonoka anomaly. Comptes Rendus Geoscience 342:204-214.

Leonov, M.V. \& A.L. Ragozina 2007. Upper Vendian assemblages of micro- and macrofossils in the White Sea region: systematic and biostratigraphic aspects. In: The rise and fall of the Ediacaran biota (P. Vickers-Rich \& P. Komarower, eds.). Geological Society of London Special Publication 386:269-275.

Ligrone, R., A. Carafa, E. Lumini, V. Biancotti, P. Bonfante \& J.G. Duckett 2007. Glomeromycotean associations in liverworts: a molecular, cellular, and taxonomic analysis. American Journal of Botany 94:1756-1777.

Lin, R. \& G.P. Ritz 1993. Reflectance FT-IR microspectroscopy of fossil algae contained in organic-rich shales. $A p$ plied Spectroscopy 47:265-271.

Liu, A.G., D. McIlroy \& M.D. Brasier 2010a First evidence for locomotion in the Ediacara biota from the $565 \mathrm{Ma}$ Mistaken Point Formation, Newfoundland. Geology 38:123-126.

Liu, A.G., D. McIlroy \& M.D. Brasier 2010b. First evidence for locomotion in the Ediacara biota from the $565 \mathrm{Ma}$ Mistaken Point Formation, Newfoundland: reply. Geology 38:e223-224

Locquin, M.V. 1983. Nouvelles recherches sur les champignons fossiles. Comptes Rendus Congrès National Sociétés des Savantes Sciences de la Terre 108:179-190.

Love, G.D., E. Grosjean, C. Stalvies, D.A. Fike, J.P. Grotzinger, A.S. Bradley, A.E. Kelly, M. Bhatia, W. Meredith, C.E. Snape, S.E. Bowring, D.J. Condon \& R.E. Summons 2009. Fossil steroids record the appearance of Demospongiae during the Cryogenian period. Nature 457:718-722.

Lücking, L.R., S. Huhndorf, D.H. Pfister, R. Plata \& H.T. Lumbsch 2009. Fungi evolved right on track. Mycologia 101:810-822.

MacDonald, F.A., M.D. Schmitz, J.L. Crowley, C.F. Roots, D.S. Jones, A.C. Maloof, J.V. Strauss, P.A. Cohen, D.T. Johnston \& D.P. Schrag 2010. Calibrating the Cryo- 
genian. Science 327:1241-1243.

Malloch, D.W., K.A. Pirozynski \& P.H. Raven 1980. Ecological and evolutionary signficance of mycorrhizal symbioses in vascular plants (a review). U.S. National Academy of Sciences Proceedings 77:2113-2118.

Maloof, A.C., C.V. Rose, R. Beach, B.M. Samuels, C.C. Calmet, D.H. Erwin, G.R. Poirier, N. Yao \& F.J. Simons 2010. Possible animal-body fossils in pre-Marinoan limestones from South Australia. Nature Geoscience 3:653-659.

Marshall, C.P, E.J. Javaux, A.H. Knoll \& M.R. Walter 2005. Combined micro-Fourier infrared (FTIR) spectroscopy and micro-Raman spectroscopy of Proterozoic acritarchs: a new approach to palaeobiology. Precambrian Research 138:208-224.

Matján, J., K. Biliková, O. Markovič, J. Gróf, G. Kogan \& J. Simúth 2007. Isolation and characterization of chitin from bumblebee (Bombus terrestris). International Journal of Biological Macromolecules 40:237-241.

Matsunaga, K.K.S., R.A. Stockey \& A.M.F. Tomescu 2013. Honeggeriella complexa gen. et sp. nov., a heteromerous lichen from the Lower Cretaceous of Vancouver Island (British Columbia, Canada). American Journal of Botany 100:450-459.

McLachlan, J., A.G. McInnes \& M. Falk 1965. Studies on the chitan (chitin: poly-n-acetylglucosamine) fibers of the diatom Thalassiosira fluviatilis Hustedt: 1 production and isolation of chitan fibers. Canadian Journal of Botany 43:707-713.

Meert, J.G., A.S. Gibsher, N.M. Levashova, W.C. Grice, G.D. Kamenov \& A.B. Ryabinin 2011. Glaciation and $\sim 770$ Ma Ediacara (?) fossils from the Lesser Karatau Microcontinent, Kazakhstan. Gondwana Research 19:867-880.

Mendelson, C.V., \& J.W. Schopf. 1991. Proterozoic and slsected early Cambrian microfossils and microfossil-like objects. In The Proterozoic biosphere (J.W. Schopf \& C. Klein, ed.), pp. 866-951. Cambridge Univ Press, Cambridge.

Moczydłowska, M., J.W. Schopf \& S. Willman 2010. Microand nano-scale ultrastructure of cell walls in Cryogenian microfossils: revealing their biological affinity. Lethaia 43:129-136.

Moczydłowska, M., E. Landing, W. Zang \& T. Palacios 2011. Proterozoic phytoplankton and the timing of chlorophyte algae origins. Palaeontology 54:721-733.

Moore, D. 2013. Fungal biology in the origin and emergence of life. Cambridge Univ Press, Cambridge, 236 pp.

Němcová, Y. 2003. Detection of cell wall structural polysaccharides by cellulase-gold and chitinase-gold complexes. Czech Phycology Olomouc 3:31-36.

Page, R.W., M.J. Jackson \& A.A. Krassay 2000. Constraining sequence stratigraphy in north Australian basins: SHRIMP U-Pb zircon geochronology between Mt Isa and McArthur River. Australian Journal of Earth Sciences 47:431-459.

Pecoits, E., K.O. Konhauser, N.R. Aubert, L.M. Heaman, G. Veroslavsky, R.A. Stern \& M.K. Gingras 2012. Bilaterian burrows and grazing behavior at $>585$ million years ago. Science 336:1693-1696.

Pekkarinen, M., J. Lom, C.A. Murphy, M.A. Ragan \& I. Dyková 2003. Phylogenetic position and ultrastructure of two Dermocystidium species (Ichthyosporea) from the common perch (Perca fluviatilis). Acta Protozoologica 42:287 -307.

Pereyra, E., M. Ingerfeld, N. Anderson, S.L.Jackson \& S. Moreno. 2006. Mucor rouxii ultrastructure: cyclic AMP and actin cytoskeleton. Protoplasma 228:189-199.

Peterson, K.J., B. Waggoner \& J.W. Hagadorn 2003. A fungal analog for Newfoundland Ediacaran fossils? Integrative and Comparative Biology 43:127-136.

Petryshyn, V.A., D.J. Bottjer, J.-C. Chen \& F. Gao 2013. Petrographic analysis of new specimens of the putative microfossil Vernanimalcula guizhouana (Doushantuo Formation, South China). Precambrian Research 225:58-63.

Pirozynski, K.A. 1976. Fungal spores in the fossil record. Biological Memoiors, Lucknow 1:104-120.

Pirozynski, K.A. \& Y. Dalpé 1989. Geological history of the Glomaceae with particular reference to mycorrhizal symbiosis. Symbiosis 7:1-36.

Pirozynski, K.A. \& D.W. Malloch 1975. The origin of land plants: a matter of mycotrophism. Biosystems 6:153-165.

Porter, S.M. 2006. The Proterozoic fossil record of heterotrophic eukaryotes. In: Neoproterozoic geobiology and paleobiology (S. Xiao \& A.J. Kaufman, eds.), pp. 1-21. Springer, Berlin.

Preiss, W.V., J.F. Drexel \& A.J. Reid 2009. Definition and age of the Kooringa Member of the Skillogalee Dolomite; host for Neoproterozoic (c. $790 \mathrm{Ma}$ ) porphyry-related copper mineralisation at Burra. MES A Journal 55:19-33.

Raevskaya, E. 2005. Diversity and distribution of Cambrian acritarchs from the Siberian and East European platforms - a generalized scheme. Carnets de Géologie Mémoire 2:1-6.

Rainbird, R.H., C.W. Jefferson \& G.M. Young 1996. The early Neoproterozoic sedimentary Succession B of northwestern Laurentia: correlations and paleogeographic significance. Geological Society of America Bulletin 108:454-470.

Rao, M.S. \& W.F. Stevens 2005. Chitin production by Lactobacillus fermentation of shrimp biowaste in a drum reactor and its chemical conversion to chitosan. Journal of Chemical and Technical Biotechnology 80:1080-1087.

Redecker, D., R. Kodner \& L.E. Graham 2000. Glomalean fungi from the Ordovician. Science 289:1920-1921.

Retallack, G.J. 2001. Scoyenia burrows from Ordovician paleosols of the Juniata Formation in Pennsylvania. Palaeontology 44:209-235.

Retallack, G.J. 2007. Decay, growth, and burial compaction of Dickinsonia, an iconic Ediacaran fossil. Alcheringa 31:215-240.

Retallack, G.J. 2008. Cambrian palaeosols and landscapes of South Australia. Australian Journal of Earth Sciences 55:1083-1106.

Retallack, G.J. 2009. Cambrian-Ordovician non-marine fossils from South Australia. Alcheringa 33:355-391.

Retallack, G.J. 2010. First evidence for locomotion in the Ediacara biota from the $565 \mathrm{Ma}$ Mistaken Point Formation, Newfoundland: comment. Geology 38:e223.

Retallack, G.J. 2011. Neoproterozoic glacial loess and limits to snowball Earth. Geological Society of London Journal 168:1-19.

Retallack, G.J. 2012. Criteria for distinguishing microbial mats and earths. In: Microbial mats in siliciclastic sediments (N. Noffke \& H. Chafetz, eds.). Society of Economic Paleontologists and Mineralogists Special Paper 101:136-152.

Retallack, G.J. 2013a. Ediacaran life on land. Nature 493:8992.

Retallack, G.J. 2013b. Comment on "Trace fossil evidence for Ediacaran bilaterian animals with complex behaviors" by Chen et al [Precambrian Res. 224 (2013) 690-701]. Precambrian Research 231:383-385.

Retallack, G.J. 2014. Volcanosedimentary paleoenvironments of Ediacaran fossils in Newfoundland. Geological Society of America Bulletin 126:619-638.

Retallack, G.J., E.S. Krull, G.D. Thackray \& D. Parkinson 2013a. Problematic urn-shaped fossils from a Paleoproterozoic (2.2 Ga) paleosol in South Africa. Precambrian Research 235:71-87. 
Retallack, G.J., K.L. Dunn \& J. Saxby 2013b. Problematic Mesoproterozoic fossil Horodyskia from Glacier National Park, Montana, USA. Precambrian Research 226: 125-142.

Retallack, G.J., A. Marconato, J.T. Osterhout, K.E. Watts \& I.N. Bindeman 2014. Revised Wonoka isotopic anomaly in South Australia and Late Ediacaran mass extinction. Journal of the Geological Society of London 171:709-722.

Rosentreter, R. 1984. Compositional patterns within a rabbitbrush (Chrysothamnus) community of the Idaho Snake River Plain. Intermountain Research Station General Technical Report INT-200:273-277.

Runnegar, B.N. \& M.A. Fedonkin 1991. Proterozoic metazoan body fossils. In: The Proterozoic biosphere: a multidisciplinary study (J.W. Schopf \& C. Klein, eds.), pp. 369-388. Cambridge Univ Press, Cambridge.

Schiffbauer, J.D., S. Xiao, K. Sen Sharma \& G. Wang 2012. The origin of intracellular structures in Ediacaran metazoan embryos. Geology 40:223-226.

Schneider, D.A., M.E. Bickford, W.F. Cannon, K.J. Schulz \& M.A. Hamilton 2002. Age of volcanic rocks and syndepositional iron formations, Marquette Range Supergroup: implications for the tectonic setting of Paleoproterozoic iron formations of the Lake Superior region. Canadian Journal of Earth Sciences 39: 999-1012.

Schoch, C.L., G.-H. Sung, F. López-Giráldez, J.P. Townsend, J. Miadlikowska, V. Hoffstetter, B. Robberts, P. B. Matheny, F. Kauff, Z. Wang, C. Gueidan, R.M. Aandrie, K. Trippe, L.M. Ciufetti, A. Wynn, E. Fraker, B.P. Hodkinson, G. Bonito, J.Z. Groenewald, et al. 2009. The Ascomycota tree of life: A phylum-wide phylogeny clarifies the origin and evolution of fundamental reproductive and ecological traits. Systematic Biology 58:224-239.

Schopf, J.W. 1999. Cradle of life: the discovery of the earth's earliest fossils. Princeton Univ. Press, Princeton, 392 pp.

Schopf, J.W. 1968. Microflora of the Bitter Springs Formation, Late Precambrian, central Australia. Journal of Paleontology 42:651-688.

Schopf, J.W. \& E.S. Barghoorn 1969. Microorganisms from the Late Precambrian of South Australia. Journal of Paleontology 43:111-118.

Schüßler, A. 2012. The Geosiphon-Nostoc endosymbiosis and its role as a model for arbuscular mycorrhiza research. In: The Mycota IX (B. Hock, ed.), pp. 77-92. Springer, Berlin.

Schüßler, A., D. Mollenhauer, E. Schnepf \& M. Kluge 1994. Geosiphon pyriforme, an endosymbiotic association of fungus and cyanobacteria: the spore structure resembles that of arbuscular mycorrhizal (AM) fungi. Botanica Acta 107:36-45.

Shen, B., L. Dong, S. Xiao \& M. Kowalewski 2008. The Avalon Explosion: evolution of Ediacara morphospace. Science 319:81-84.

Sherwood-Pike, M. 1991. Fossils as keys to evolution in fungi. Biosystems 25:121-129.

Sherwood-Pike, M.A. \& J. Gray 1985. Silurian fungal remains: probable remains of Class Ascomycetes. Lethaia 18:1-20.

Shu, D.-G., S. Conway Morris, J. Han, Y. Li, X.-L. Zhang, H. Hua, Z.-F. Zhang, Z.-F., J.-N. Liu, J.-F. Huo, Y.Yao \& Y. Yasui 2005. Lower Cambrian vendobionts from China and early diploblast evolution. Science 314:731-734.

Sieverding, E. \& F. Oehl 2006. Revision of Entrophospora and description of Kuklospora and Intraspora, two new genera in the arbuscular mycorrhizal glomeromycetes. Journal of Applied Botanical Food Quality 80:69-81.

Sini, T.K., S. Santosh \& T.M. Paruthapara 2007. Study on the production of chitin and chitosan from shrimp shell by using Bacillus subtilis fermentation. Carbobydrate Research 342:2423-2429.

Stebbins, G.L. \& G.J.C. Hill 1980. Did multicellular plants invade the land? American Naturalist 115:342-353.

Strother, P.K., L. Battison, M.D. Brasier \& C.H. Wellman 2011. Earth's earliest non-marine eukaryotes. Nature 473: 505-509.

Stürmer, S.L. \& J.B. Morton. 1999. Taxonomic reinterpretation of morphological characters in Acaulosporaceae based on developmental patterns. Mycologia 91:849-857.

Sun, W.-G., G.-X. Wang \& B.-H. Zhou 1986. Macroscopic worm-like body fossils from the upper Precambrian (900-700 Ma), Huainan district, Anhui, China, and its stratigraphic and evolutionary significance. Precambrian Research 31:377-403.

Talyzina, N.M. \& M. Moczydłowska 2000. Morphological and ultrastructural studies of some acritarchs from the Lower Cambrian Lükati Formation, Estonia. Review of Palaeobotany \& Palynology 112:1-21.

Taylor, J.W. \& M.L. Berbee 2006. Dating divergences in the fungal tree of life: review and new analyses. Mycologia 98:838-849.

Taylor, T.N. \& J.M. Osborn 1996. The importance of fungi in shaping the paleoecosystem. Review of Palaeobotany \& Palynology 90:249-262.

Taylor, T.N. \& E.L. Taylor 2000. The Rhynie Chert ecosystem: a model for understanding fungal interactions. In: Microbial Endophytes (C.W. Bacon \& J.F. White, eds.), pp. 31-47. Marcel Dekker, New York.

Taylor, T.N., H. Hass \& H. Kerp 1997. A cyanolichen from the Lower Devonian Rhynie Chert. American Journal of Botany 84:992-1004.

Taylor, T.N., H. Hass, H. Kerp, M. Krings, \& R.T. Hanlin. 2005. Perithecial ascomycetes from the 400 million year old Rhynie chert: an example of ancestral polymorphism. Mycologia 97:269-285.

Taylor, T.N., M. Krings \& E.L. Taylor 2014. Fossil fungi. Academic Press, London, 382 pp.

van Etten, J.L. \& R.H. Meints 1999. Giant viruses infecting algae. Annual Reviews of Microbiology 53:447-494.

van Kranendonk, M.J., J.G. Gehling \& G.A. Shields 2008. Precambrian. In: The concise geologic time scale (J.G. Ogg, G. Ogg \& F.M. Gradstein, eds.), pp. 22-36. Cambridge University Press, Cambridge.

Vanguestaine, P. \& P.M. Brück 2008. A Middle and Late Cambrian age for the Booley Bay Formation, County Wexford, Ireland: new acritarch data and its implications. Revue de Micropaléontogie 51:67-95.

Vecoli, M. \& A. Le Hérissé 2004. Biostratigraphy, taxonomic diversity and patterns of morphological evolution of Ordovician acritarchs (organic-walled microphytoplankton) from the northern Gondwana margin in relation to paleoclimatic and paleogeographic changes. Earth Science Reviews 67:267-311.

Vidal, G. \& M. Moczydłowska-Vidal 1997. Biodiversity, speciation and extinction trends of Proterozoic and Cambrian phytoplankton. Paleobiology 23:230-246.

Wang, B. \& Y.-L. Qiu 2006. Phylogenetic distribution and evolution of mycorrhizas in land plants. Mycorrbiza 16:299-363.

Walker, C. 1983. Taxonomic concepts in the Endogonaceae: spore wall characteristics in species descriptions. Mycotaxon 18:443-455.

Walker, C., J. Błaskowski, D. Schwarzott \& A. Schüßler 
2004. Gerdemannia gen. nov. a genus separated from Glomus and Gerdemanniaceae fam. nov, a new family in the Glomeromycota. Mycological Research 108:707-718.

Wilby, P.R., J.N. Carney \& M.P.A. Howe 2011. A rich Ediacaran assemblage from eastern Avalonia: evidence of early widespread diversity in the deep ocean. Geology 39:655-658.

Willman, S. 2009. Morphology and wall ultrastructure of leiosphaeric and acanthomorphic acritarchs from the Ediacaran of Australia. Geobiology 7:8-20.

Willman, S. \& M. Moczydłowska 2007. Wall ultrastructure of an Ediacaran acritarch from the Officer Basin, Australia. Lethaia 40:111-123.

Wu, C.-G., Y.-S. Liu, Y.-L. Hwuang, Y.-P. Wang \& C.-C. Chao 1995. Glomales of Taiwan: V. Glomus chimonobambusae and Entrophospora kentinensis spp. nov. Mycotaxon 53:283-294.

Wu, T., S. Zivanovic, F.A. Draughton, W.S. Conway \& C.E. Sams 2005. Physicochemical properties and bioactivity of fungal chitin and chitosan. Journal of Agricultural Food Chemistry 53:3888-3894.

Xiao, S., A.H. Knoll, X. Yuan \& C.M. Pueschel 2004. Phosphatized multicellular algae in the Neoproterozoic Doushantuo Formation, China, and the early evolution of florideophyte red algae. American Journal of Botany 91:214-227.
Xiao, S., A.H. Knoll, J.D. Schiffbauer, C. Zhou \& X. Yuan 2012. Comment on Fossilized nuclei and germination structures identify Ediacaran animal embryos as encysting protists. Science 335:1169.

Yin, L. 1997. Acanthomorphic acritarchs from Meso-Neoproterozoic shales of the Ruyang Group, Shanxi, China. Review of Palaeobotany \& Palynology 98:15-25.

Yin, Z., M. Zhua, P. Tafforeau, J. Chen, P. Liu \& G. Li 2013. Early embryogenesis of potential bilaterian animals with polar lobe formation from the Ediacaran Weng'an Biota, South China. Precambrian Research 225:44-57.

Yuan, X., S. Xiao, J. Li, L.Yin \& R. Cao 2001. Pyritized chuarids with excystment structures from the late Neoproterozoic Lantian formation in Anhui, South China. Precambrian Research 107:253-263.

Yuan, X., S. Xiao \& T.N. Taylor 2005. Lichen-like symbiosis 600 million years ago. Science 308:1017-1020.

Zhang, X.-G., B.R. Pratt \& C. Shen 2011. Embryonic development of a Middle Cambrian (500 MYR old) scalidophoran worm. Journal of Paleontology 85:898-903.

\section{Greg Retallack:}

On discovering Valentin Krassilov's marvellous 1977 book "Paleoecology of terrestrial plants", I at first felt scooped, but then overwhelmed at the range of examples and sweep of ideas. In my mind's eye I pictured him as a jocund and rotund senior scientist of vast experience, much nose hair and an ill-fitting suit, like many Russian scientists of the time. To my great surprise on meeting him for the first time at the 1984 International Geological Congress in Moscow, I found that he was little older than me, athletic, very fashionably dressed, and with an attractive young wife. He had an intensity and seriousness of purpose that was fascinating. This was just the beginning of his career, and yet he had already accomplished so much. 